\title{
Petrologic and geochemical constraints on the petrogenesis of Permian-Triassic Emeishan flood basalts in southwestern China
}

\author{
Yigang $\mathrm{Xu}^{\mathrm{a}, *}$, Sun-Lin Chung ${ }^{\mathrm{b}}$, Bor-ming Jahn ${ }^{\mathrm{c}}$, Genyao $\mathrm{Wu}^{\mathrm{d}}$ \\ a Guangzhou Institute of Geochemistry, Chinese Academy of Sciences, 510640 Wushan, Guangzhou, China \\ ${ }^{\mathrm{b}}$ Department of Geology, National Taiwan University, Taipei, Taiwan \\ ${ }^{\mathrm{c}}$ Geosciences Rennes-CNRS, Université de Rennes 1, 35042 Rennes Cedex, France \\ ${ }^{\mathrm{d}}$ Institute of Geology and Geophysics, Chinese Academy of Sciences, 100029 Beijing, China
}

Received 15 December 2000; accepted 19 July 2001

\begin{abstract}
The Emeishan flood basalt is a large igneous province erupted during the Permian-Triassic period in southwestern China. Based on petrographic, major and trace element, and $\mathrm{Sr}-\mathrm{Nd}$ isotope data, the Emeishan basalts can be classified into two major magma types. These are: (1) a low-Ti (LT) type that exhibits low $\mathrm{Ti} / \mathrm{Y}(<500), \mathrm{Fe}_{2} \mathrm{O}_{3}^{*}(<12 \%), \mathrm{Nb} / \mathrm{La}(0.6-1.4)$, $\varepsilon_{\mathrm{Nd}}(t)(-4.8$ to +1.4$)$ and relatively high $\mathrm{SiO}_{2}(48-53 \%)$ and $\mathrm{Mg \#}(0.52-0.64) ;(2)$ a high-Ti (HT) type that has high $\mathrm{Ti} / \mathrm{Y}(>500)$. The HT lavas can be further divided into three subtypes. HT1 lavas exhibit significantly high $\mathrm{TiO}_{2}$ (3.65-4.7\%), $\mathrm{Fe}_{2} \mathrm{O}_{3}^{*}(12.7-16.4 \%), \mathrm{Nb} / \mathrm{La}(0.75-1.1)$, coupled with higher $\varepsilon_{\mathrm{Nd}}(t)(1.1-4.8)$ and lower $\mathrm{SiO}_{2}(45-51 \%)$; HT2 lavas are compositionally similar to the HT1 lavas but show conspicuous depletion in U and Th. The HT3 type has higher Mg\# (0.51-0.61) than the HT1 and HT2 lavas. It differs from the LT type in having higher $\mathrm{TiO}_{2}(\sim 3 \%)$ at comparable Mg\#. Elemental and isotopic data suggest that the chemical variations of the LT and HT lavas cannot be explained by crystallization from a common parental magma. Instead, they may originate from different mantle sources under various melting conditions and underwent distinct differentiation and contamination processes. REE inversion calculations indicate that the HT magmas were generated by low degrees of partial melting $(1.5 \%)$ of a mantle source that has $\varepsilon_{\mathrm{Nd}}(t)$ of $\sim+5$ and ${ }^{87} \mathrm{Sr} /{ }^{86} \mathrm{Sr}(t)$ of $\sim 0.704$ within the garnet stability field. These magmas were then subjected to shallow level gabbroic fractionation, which led to larger chemical variations. In contrast, parental magmas of the LT type were generated by higher degree of partial melting $(16 \%)$ of a distinct mantle source $\left(\varepsilon_{\mathrm{Nd}}(t) \approx+2,{ }^{87} \operatorname{Sr} /{ }^{86} \operatorname{Sr}(t) \approx 0.705\right)$ around the spinel-garnet transition zone. The chemical evolution of the LT lavas is controlled by an olivine (ol) + clinopyroxene (cpx) fractionation. The Emeishan flood basalts may result from a starting mantle plume. The petrogenesis of both the LT and HT magmas was further complicated by contamination of upper crust and lithospheric mantle. While the HT1 lavas have experienced an AFC style of contamination in the upper crust, the HT2 lavas that mark with U-Th depletions may result from additional interaction with melts derived from a gabbroic layer near the crust-mantle boundary. In contrast, a temperature-controlled style of contamination was associated with the LT lavas. Our data show that both temporal and spatial geochemical variations exist in the Emeishan flood basalt province. The occurrence of thick LT lavas in the western part of the province may record the main episode of the flood basalt emplacement. In contrast, the less abundant
\end{abstract}

\footnotetext{
* Corresponding author. Tel.: +86-20-8529-0109; fax: +86-20-8529-0130.

E-mail address: yigangxu@gig.ac.cn (Y. Xu).
} 
overlying HT basalts may imply a waning activity of the plume. In fact, the HT basalts are the dominant magma type in the periphery of the province. The lower degrees of mantle melting of the HT lavas may be a result of relatively thicker lithosphere and lower geotherm. (C) 2001 Elsevier Science B.V. All rights reserved.

Keywords: Emeishan flood basalts; Geochemistry; Petrogenesis; Mantle plume; SW China

\section{Introduction}

Not until recently, the Emeishan flood basalt in southwestern China has been recognized as one of the large igneous provinces (LIP) (Coffin and Eldholm, 1994; Mahoney and Coffin, 1997; Chung and Jahn, 1995; Chung et al., 1998). Previous studies were focused on the high-Mg magmas or picrites that are generally believed to have occurred in the axis of mantle plumes and/or represent the melting product of plume tails (Campbell and Griffiths, 1990). A general model involving plume-lithosphere interaction has been proposed for geochemical and isotopic variations observed in the Emeishan picrites (Chung and Jahn, 1995). This paper presents an extended study on the petrology and geochemistry of dominant basaltic lavas in the Emeishan LIP. New major, trace element and $\mathrm{Sr}-\mathrm{Nd}$ isotopic data of the basaltic rocks collected from several representative thick sections (up to $5 \mathrm{~km}$ ) in Sichuan and Yunnan Provinces are reported. These data allow us to identify four magma types (i.e., low-Ti type and three subtypes of high-Ti lavas). We will address important aspects of the petrogenesis of these magma types, such as mantle melting conditions, shallowlevel differentiation and relative contribution of the mantle and crust components in magma generation, as well as geodynamic implication of temporal and spatial relationships between the high- $\mathrm{Ti}$ and low-Ti magmas.

\section{Geological background}

The Emeishan LIP is located in the western margin of the Yangtze craton, SW China (Fig. 1). The basement of Emeishan LIP consists mainly of metamorphic rocks of Middle Proterozoic age (Zhai and Yang, 1986). Since the early Permian, thick ( $>1$ $\mathrm{km})$ carbonate sequences began to deposit as a re- sponse to extensive transgression and basin subsidence (Yunnan, 1990; Sichuan, 1991). The basement subsidence was probably related to the rifting of the Qiangtang Terrane off South China (Huang et al., 1992). Later, rapid basement uplift took place before the main eruption of the Emeishan LIP. This uplift seems to have been a regional event that resulted in a general lack of sedimentary deposition from the uppermost Permian to the lower Triassic in the western part of the South China Block (Chung et al., 1998 and references therein). Consequently, the massive volcanic successions cover uncomfortably on the early Late Permian Maokou formation, which corresponds to the Capitanian/Kazanian stage. Therefore, the eruption age of the overlying magmas should be nearly coeval to or younger than the Longtainian of 253-258 Ma (Harland et al., 1989). Limited Ar-Ar dating results of the basaltic lavas and associated intrusives show that the Emeishan LIP was emplaced at 253-250 Ma (Chung et al., unpublished data) around the Permian-Triassic boundary. The lack of thick sedimentary piles or paleosols within the volcanic sections implies a short eruption period of the entire sequence. This is consistent with the result of a recent magnetostratigraphic study that suggests a magmatic duration of the Emeishan flood basalt $<2$ Ma (Huang and Opdyke, 1998). The eruption of the Emeishan basalts is roughly synchronous with that of the Siberian traps (250 $\pm 1 \mathrm{Ma}$; Renne et al., 1995). Huge-volume magma eruption over a few million years may have triggered the environmental catastrophe accompanied by the greatest mass extinction at the Permian-Triassic boundary (Chung et al., 1998).

The Emeishan basalts are exposed in a rhombic province of $\sim 250000 \mathrm{~km}^{2}$ within Yunnan, Sichuan and Guizhou Provinces (Fig. 1). The Red River shear zone is traditionally considered as its western boundary (e.g., Zhang et al., 1988). However, some basalts and mafic complexes exposed in the Simao basin, northern Vietnam and Qiangtang terrain are possibly an extension of the Emeishan LIP (Chung et al., 


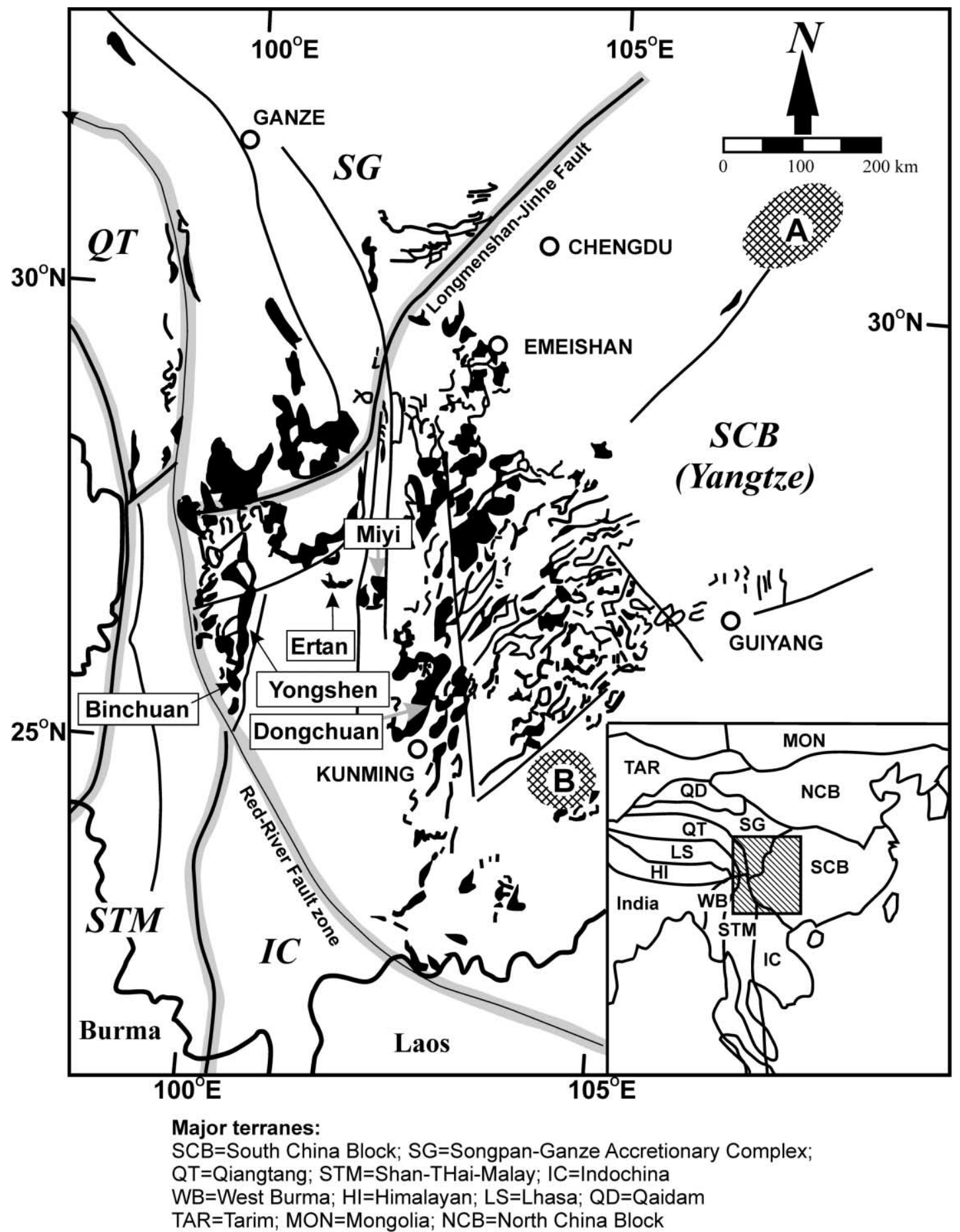

Fig. 1. Schematic map showing the distribution of the Permian-Triassic volcanic successions (black areas) in the Emeishan basalt province and adjacent regions (modified after Chung et al., 1998). The inset illustrates major tectonic unites in eastern Asia. The shaded areas, marked with A and B, indicate subsurface mafic volcanic succession as revealed by drilling studies. Arrows indicate the sampling localities. 


\section{Binchuan}

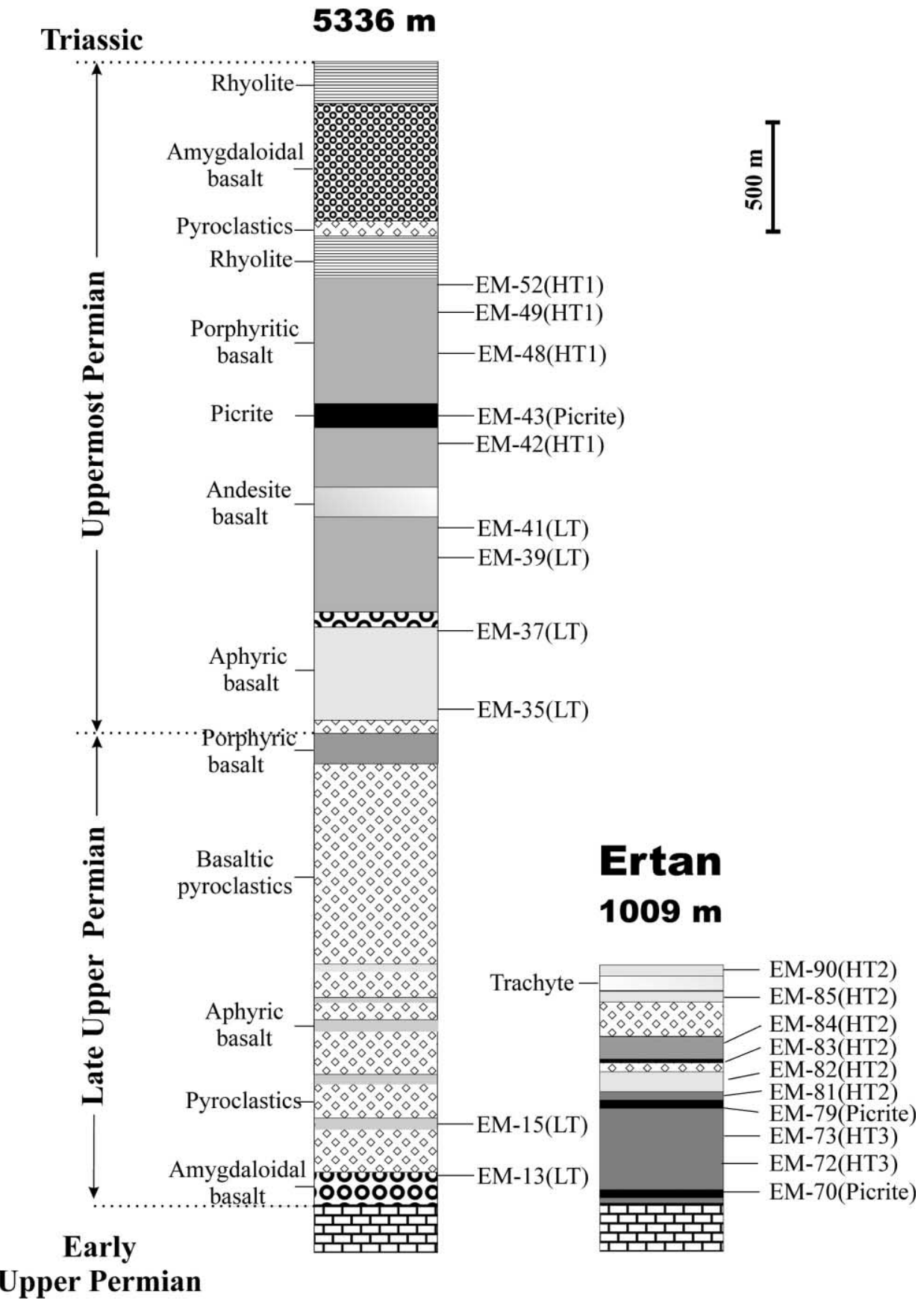

Fig. 2. Composite stratigraphic columns at Binchuan and Ertan (modified after Huang, 1986). Relative stratigraphic locations and magma type of studied samples in the volcanic sections are also shown. Each shaded part represents individual lava flow. Analyses of picrites (except for EM-43) can be found in Chung and Jahn (1995). 
1998). Some Emeishan-type basalts traced in northern Vietnam may be related to the mid-Tertiary continental extrusion of Indochina relative to South China along the Ailao Shan-Red River fault zone (Tapponnier et al., 1990; Chung et al., 1997). It is likely that the later tectonic events have resulted in major disruption of the former province. The three dimensional structure of the Emeishan LIP is poorly known, but its east-west thickness variation in volcanic successions has been reported by Lin (1985) and Huang (1986). The thickness varies from over $5000 \mathrm{~m}$ in the west (i.e., in Yunnan Province) to several hundred meters in the east (i.e., in Guizhou Province). The average lava thickness of the LIP was estimated to be about $700 \mathrm{~m}$ (Lin, 1985), thus the entire volume of the Emeishan basalts to be $\sim 0.3 \times$ $10^{6} \mathrm{~km}^{3}$. This represents a minimum estimate because: (1) complicated tectonic movements in $\mathrm{Me}$ so-Cenozoic eras in this region cut off the western extension of the LIP (Chung et al., 1998); (2) erosion must have removed a significant portion of the eruptive sequences; and (3) the associated intrusives are not taken into account.

The lateral variation in lava thickness is accompanied by variations in lithology and geochemical characteristics (Huang, 1986; Zhang et al., 1988). In the west, the Emeishan lavas show a remarkable diversity of rock type including picrite, basalt, basaltic andesite, rhyolite-trachyte and basaltic pyroclastics. Furthermore, tuffs of trachyte and rhyolite composition occur in the upper volcanic sequence (Fig. 2; Huang, 1986; Chung et al., 1998). Such a compositional bimodality is also revealed by the associated intrusive rocks that comprise syneites and layered gabbros. Some of syneites and gabbros are associated with massive $\mathrm{V}-\mathrm{Ti}-\mathrm{Fe}$ ore deposits (Sichuan, 1991). In contrast, the lavas emplaced in the east part of the Emeishan LIP are uniformly tholeiitic-alkali basalts. They are characterized by rather high $\mathrm{TiO}_{2}$ (3.6-5\%) and low $\mathrm{MgO}(<6 \%)$ contents (Lin, 1985; Huang, 1986), suggesting an evolved basaltic magma composition.

\section{Sampling and analytical techniques}

Samples studied in this paper are from a reconnaissance collection of basalts from Binchuan and
Yongshen in western Yunnan Province, and from Ertan and Miyi in southern Sichuan Province (Fig. 1). Two additional samples (EM-1 and EM-3) were collected from the uppermost lava sequence in Dongchuan area (eastern Yunnan). Unfortunately, systematic sampling of volcanic succession with a stratigraphic height control was not possible due to the poor exposure and severe weathering/alteration of the lava flows. This prevents from detail geochemical assessment of the temporal evolution of these rocks. The samples collected, nevertheless, show various lithology including picrite, tholeiite, basaltic andesite, rhyolite and trachyte, in the documented stratigraphic columns (Fig. 2).

Twenty-five basalts and one picrite were analyzed in this study. These include fresh (with loss on ignition, $\mathrm{LOI}<1 \%$ ) to altered (LOI of $3-4 \%$ ) samples. The rocks were sawn into slabs and the central portions were handpicked and powered using an agate mill. Whole-rock abundances of major and some trace $(\mathrm{Rb}, \mathrm{Ba}, \mathrm{Sr}, \mathrm{Nb}, \mathrm{Ni}, \mathrm{Cr}, \mathrm{Zr}, \mathrm{Co}, \mathrm{Y}, \mathrm{V}$, $\mathrm{Zn}, \mathrm{Cu}$ and $\mathrm{Ga}$ ) elements were determined on glass discs and pressed pellets, respectively, using a Philips PW1400 X-ray fluorescence spectrometer at Université de Rennes I. Additional trace element data [e.g., the rare earth elements (REE), Th, U, Hf and Ta] were measured by the instrumental neutron activation analysis (INAA) at National Taiwan University. The analytical uncertainties were estimated to be generally $<1 \%$ for the major elements and $5-15 \%$ for the trace elements. The $\mathrm{Sr}-\mathrm{Nd}$ isotopic ratios were obtained by a Finnigan MAT262 mass spectrometer at Université de Rennes I. Details of all the analytical methods were described by Chung et al. (1995).

\section{Results}

\subsection{Classification of the Emeishan basalts}

For the convenience of description and following the studies in other continental flood basalts (CFB), we divide the Emeishan flood basalts into two major magma types: high- $\mathrm{Ti}(\mathrm{HT}, \mathrm{Ti} / \mathrm{Y}>500)$ and low-Ti (LT, $\mathrm{Ti} / \mathrm{Y}<500$ ) basalts. $\mathrm{Ti} / \mathrm{Y}$, rather than $\mathrm{TiO}_{2}$, is used as a discriminator of rock types, because 
$\mathrm{TiO}_{2}$ contents generally increase but $\mathrm{Ti} / \mathrm{Y}$ does not vary much during fractional crystallization (Peate et al., 1992). Fig. 3 shows that $\mathrm{Ti} / \mathrm{Y}$ in the Emeishan basalts is somewhat correlated with $\mathrm{Mg \#}$ (indicator of differentiation), $\mathrm{Sm} / \mathrm{Yb}$ (degree of HREE fractionation, hence depth of magma generation) and $\varepsilon_{\mathrm{Nd}}(t)$ (nature of source or extent of lithospheric assimilation). In general, the LT lavas have higher $\mathrm{Mg} \#$, lower $\mathrm{Sm} / \mathrm{Yb}$ ratio and $\varepsilon_{\mathrm{Nd}}(t)$ compared to most HT lavas. However, $\mathrm{Mg \#}$ of four HT samples (EM-72, EM-73, EM-93, EM-99) overlap that of the LT lavas. These samples, designated as HT3 magma type, also show low $\varepsilon_{\mathrm{Nd}}(t)$ compared to the remaining HT lavas. The latter are further subdivided into

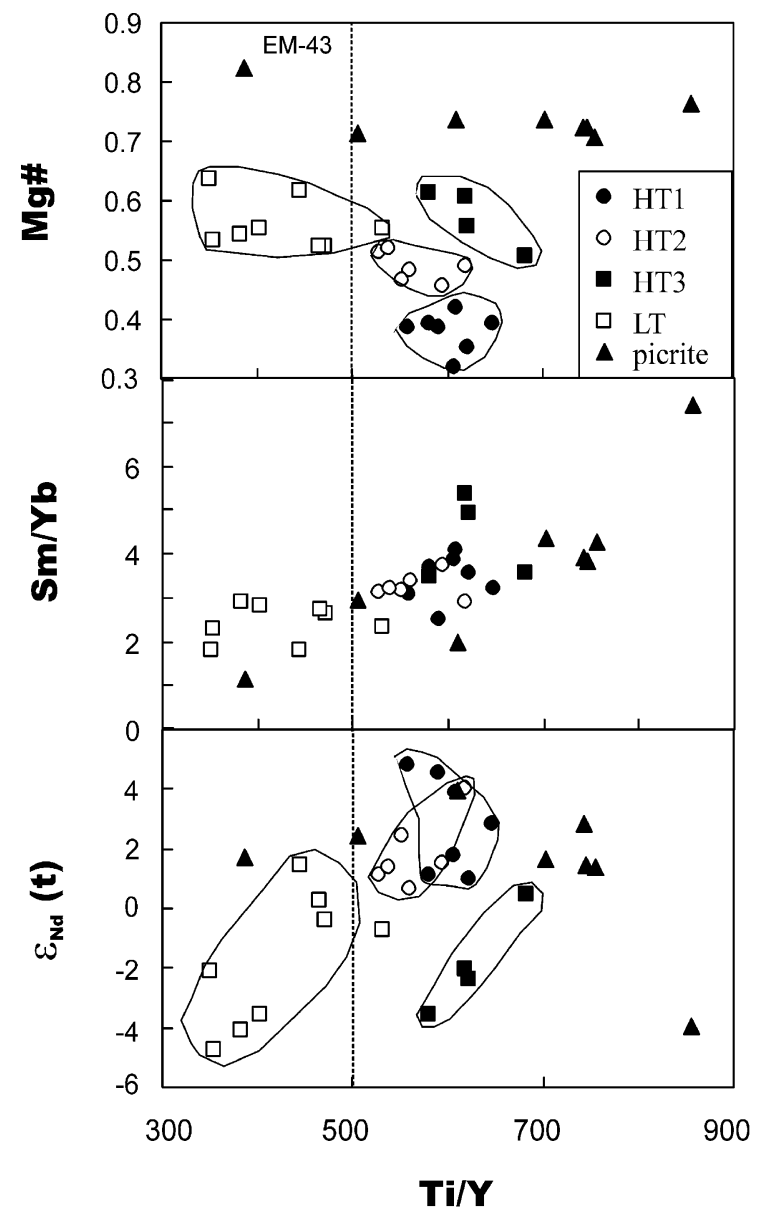

Fig. 3. Diagram showing variation of $\mathrm{Mg} \#, \mathrm{Sm} / \mathrm{Yb}$ and $\varepsilon_{\mathrm{Nd}}(t)$ against $\mathrm{Ti} / \mathrm{Y}$ for the Emeishan basalts. Data for picrites are from Chung and Jahn (1995).
HT1 $\left(\mathrm{TiO}_{2}>3.6 \%, \mathrm{Mg} \#<0.45\right)$ and HT2 $\left(\mathrm{TiO}_{2}<\right.$ $2.5-3.5 \%, \mathrm{Mg} \#=0.45-0.52)$. The HT2 magma type contains six samples from the Ertan section (EM-78, EM-81, EM-82, EM-84, EM-85, EM-90), which show peculiar petrographic feature and trace element composition when compared to the HT1 lavas (see next sections). This classification is rather preliminary and could be refined when more data are available. Nevertheless, it will be justified further in later sections because the HT and LT magma types are believed to have originated from different mantle sources under various melting conditions followed by different petrogenetic processes.

Two types of picrites can also be distinguished in terms of this classification. EM-43 from Binchuan has low $\mathrm{Ti} / \mathrm{Y}$ and $\mathrm{Sm} / \mathrm{Yb}$ ratios and plot with the field of LT lavas (Fig. 3). In contrast, other picrites from Yongshen and Ertan show compositional affinity to the HT lavas.

\subsection{Petrography}

Distinct petrographic features are noted for different magma types in terms of phenocryst and groundmass compositions (Table 1), although both aphyric and phyric textures are observed in the LT and HT lavas. The dominant phenocryst in the LT samples is clinopyroxene $(25-30 \%)$ with occasionally minor olivine $(<10 \%)$. Plagioclase phenocryst is generally absent in this magma type. The groundmass is composed of plagioclase (35-64\%), clinopyroxene (15$44 \%)$, basaltic glasses or microlite $(15-18 \%)$ and minor magnetite $(1-4 \%)$. A similar petrographic feature is noted for the HT3 lavas. In contrast, plagioclase is the dominant phenocryst in the HT1 and HT2 samples that also exhibit relatively high contents of magnetite (3-8\%) in groundmass. In detail, the HT1 lavas show relatively lower contents of plagioclase phenocrysts $(4-10 \%)$ than the HT2 basalts (13-33\%). The latter contain large and tabular plagioclases $(>5 \mathrm{~mm}$ ) which commonly form as aggregates with a "flower-like" shape. Clinopyroxene phenocryst of variable amount $(3-10 \%)$ is exclusively observed in HT2 samples (EM-82, EM-84, EM-85). The groundmass in the HT1 lavas predominantly contains plagioclase $(50-60 \%)$ and microlite $(32-42 \%)$. Its magnetite content is relatively low 
Table 1

Petrographic characteristics of the Emeishan flood basalts

\begin{tabular}{|c|c|c|}
\hline & Phenocryst & Groundmass \\
\hline Low-Ti type (LT) & $\begin{array}{l}\text { cpx }(25-30 \%) \\
\text { occasionally ol }(<10 \%)\end{array}$ & $\begin{array}{l}\text { plagioclase }(35-64 \%), \mathrm{cpx}(15-44 \%) \\
\text { basaltic glasses }(15-18 \%) \text {, magnetite }(1-4 \%)\end{array}$ \\
\hline High-Ti type (HT1) & plagioclase (4-10\%) & $\begin{array}{l}\text { plagioclase }(50-60 \%) \\
\text { basaltic glass }(32-42 \%) \\
\text { magnetite }(3-5 \%)\end{array}$ \\
\hline High-Ti type (HT2) & $\begin{array}{l}\text { plagioclase }(13-33 \%) \\
\text { cpx }(3-10 \%)\end{array}$ & $\begin{array}{l}\text { plagioclase }(21-44 \%), \mathrm{cpx}(14-40 \%) \\
\text { basaltic glass }(16-25 \%), \mathrm{Ti}-\mathrm{Fe} \text { biotite }(4-10 \%) \\
\text { magnetite }(5-8 \%)\end{array}$ \\
\hline High-Ti type (HT3) & cpx $(20-30 \%)$ & $\begin{array}{l}\text { plagioclase }(40-60 \%), \mathrm{cpx}(15-40 \%) \\
\text { basaltic glasses }(15-20 \%), \text { magnetite }(3-6 \%)\end{array}$ \\
\hline
\end{tabular}

(3-5\%), contrasting with the significant amount of clinopyroxene $(14-40 \%)$ and magnetite $(5-8 \%)$ in the groundmass of the HT2 lavas. Another noteworthy point is that the HT2 samples contain a variable amount of Ti-Fe-rich biotite (4-10\%).

\subsection{Major and minor elements}

The Emeishan basalts display wide variations in major element composition (Table 2). In general, the HT1 lavas $(\mathrm{Mg} \#=0.45-0.31)$ are more evolved than the LT samples $(\mathrm{Mg} \#=0.63-0.51)$, with the HT2 lavas being compositionally transitional between them. Mg\# of HT3 lavas overlap with that of LT samples. But HT3 lavas have higher $\mathrm{TiO}_{2}$ and lower $\mathrm{Al}_{2} \mathrm{O}_{3}$ contents than the LT basalts at comparable $\mathrm{Mg} \#$ (Fig. 4b,d). Mg\# negatively correlates with $\mathrm{TiO}_{2}$, and $\mathrm{Fe}_{2} \mathrm{O}_{3}$ (Fig. 4b,e). However, there is no simple correlation between $\mathrm{Mg} \#$ and $\mathrm{CaO}, \mathrm{SiO}_{2}$ and $\mathrm{Al}_{2} \mathrm{O}_{3}$ (Fig. 4a,c,d). For example, Mg\# negatively correlates with $\mathrm{SiO}_{2}$, but the HT1 and HT2 lavas and LT samples define two different trends (Fig. 4c). The HT2 lavas have lower $\mathrm{SiO}_{2}$ than the LT basalts at comparable $\mathrm{Mg} \#$. $\mathrm{CaO}$ and $\mathrm{Al}_{2} \mathrm{O}_{3}$ in the LT samples increase with decreasing $\mathrm{Mg} \#$, but reverse trends are noted for the HT1 and HT2 lavas although trends are poorly defined (Fig. 4c,d). The picrites are distinguished from the basalts by their high $\mathrm{Mg} \#$, low $\mathrm{SiO}_{2}, \mathrm{Al}_{2} \mathrm{O}_{3}$ and $\mathrm{Na}_{2} \mathrm{O}$ contents.

The HT1 and HT2 basalts show a rather low and limited range of nickel content (53-102 ppm) which correlates positively with Mg\# (Fig. 5a). Some LT and HT3 samples display a distinctive trend with $\mathrm{Ni}$ contents dramatically decreasing from $200 \mathrm{ppm}$ at $\mathrm{Mg} \#$ of 0.63 to $<10 \mathrm{ppm}$ at $\mathrm{Mg} \#$ of 0.50 . The picrites show significantly higher $\mathrm{Ni}$ contents (up to $1100 \mathrm{ppm}$ ), consistent with their abundant olivine phenocrysts (Chung and Jahn, 1995) which exhibit high-Mg contents $(\mathrm{Fo} \approx 83-89 ; \mathrm{Xu}$ and Chung, 2001). Cr also correlates positively with $\mathrm{Mg \#}$, whereas $\mathrm{V}, \mathrm{Cu}$ and $\mathrm{Zr}$ negatively correlate with $\mathrm{Mg} \#$ (Fig. 5). In the plot of Sr vs. Mg\#, Sr contents in the LT and the HT2 basalts increases with decreasing Mg\#, whereas the HT1 samples are significantly off the negative correlation (Fig. 5e). Consistent with the observation in terms of major element composition, the picrites and basalts do not form coherent trends in variation diagram between minor elements (except for $\mathrm{Cr}$ ) and $\mathrm{Mg \#}$.

\subsection{Incompatible trace elements}

The variation in trace element composition in the Emeishan basalts is correlated with their $\mathrm{TiO}_{2}$ contents and petrographic features (Table 2). In the primitive-mantle normalized spidergrams, the HT1 lavas are characterized by depletion of $\mathrm{Rb}$ and $\mathrm{Ba}$ relative to Th (except for EM-97) and by marked negative $\mathrm{Sr}$ anomaly (Fig. 6a). Slight negative $\mathrm{Nb}$ anomaly is noted in samples of this group. The HT2 lavas (except for EM-90) display marked positive Ba anomalies that are associated with the formation of significantly negative $\mathrm{Th}$ and $\mathrm{U}$ anomalies. Unlike the HT1 samples, only weak $\mathrm{Sr}$ anomaly is present in the HT2 lavas (Fig. 6b). Negative Eu anomaly is observed in some of the samples. Enrichment of $\mathrm{Rb}$ 
Table 2

Representative major and trace element data for the Emeishan flood basalts

\begin{tabular}{|c|c|c|c|c|c|c|c|c|c|c|c|c|c|}
\hline \multirow[t]{3}{*}{ Locality } & \multicolumn{9}{|c|}{ Low-Ti basalts (LT) } & \multicolumn{4}{|c|}{ High-Ti basalts (HT1) } \\
\hline & EM-13 & EM-15 & EM-35 & EM-37 & EM-39 & EM-41 & EM-43 & EM-95 & EM-98 & EM-01 & EM-03 & EM-42 & EM-48 \\
\hline & \multicolumn{7}{|c|}{ Binchuan } & \multicolumn{2}{|l|}{ Miyi } & \multicolumn{2}{|c|}{ Dongchuan } & \multicolumn{2}{|c|}{ Binchuan } \\
\hline \multicolumn{14}{|c|}{ in percent $(\%)$} \\
\hline $\mathrm{SiO}_{2}$ & 48.00 & 53.22 & 50.76 & 49.33 & 49.48 & 49.13 & 41.86 & 49.97 & 50.06 & 51.09 & 49.87 & 46.96 & 45.71 \\
\hline $\mathrm{TiO}_{2}$ & 1.52 & 1.65 & 2.08 & 2.04 & 1.86 & 1.78 & 0.58 & 2.28 & 2.33 & 4.55 & 4.66 & 4.00 & 4.13 \\
\hline $\mathrm{Al}_{2} \mathrm{O}_{3}$ & 13.50 & 13.34 & 13.53 & 13.53 & 15.19 & 13.09 & 6.99 & 13.41 & 13.55 & 12.80 & 12.90 & 12.82 & 13.05 \\
\hline $\mathrm{Fe}_{2} \mathrm{O}_{3}$ & 11.93 & 10.32 & 11.00 & 11.19 & 11.21 & 11.13 & 11.08 & 11.50 & 11.76 & 15.11 & 15.67 & 15.99 & 16.40 \\
\hline $\mathrm{MgO}$ & 10.43 & 5.93 & 6.84 & 6.72 & 6.96 & 8.99 & 25.70 & 6.38 & 6.47 & 3.59 & 4.29 & 5.06 & 5.18 \\
\hline $\mathrm{CaO}$ & 9.62 & 8.45 & 7.96 & 8.92 & 7.48 & 7.80 & 7.30 & 9.39 & 10.03 & 7.54 & 7.05 & 10.68 & 9.12 \\
\hline $\mathrm{Na}_{2} \mathrm{O}$ & 1.12 & 3.39 & 3.79 & 3.27 & 4.22 & 4.16 & 0.16 & 3.08 & 2.22 & 2.69 & 2.42 & 2.23 & 3.30 \\
\hline $\mathrm{K}_{2} \mathrm{O}$ & 0.67 & 0.76 & 1.07 & 0.77 & 0.36 & 0.22 & 0.09 & 1.19 & 0.62 & 0.92 & 0.80 & 0.55 & 0.60 \\
\hline $\mathrm{MnO}$ & 0.17 & 0.15 & 0.15 & 0.17 & 0.15 & 0.20 & 0.18 & 0.17 & 0.17 & 0.23 & 0.25 & 0.21 & 0.28 \\
\hline $\mathrm{P}_{2} \mathrm{O}_{5}$ & 0.16 & 0.23 & 0.23 & 0.22 & 0.18 & 0.16 & 0.12 & 0.22 & 0.22 & 0.52 & 0.53 & 0.42 & 0.43 \\
\hline LOI & 2.79 & 2.47 & 2.44 & 3.50 & 2.93 & 3.21 & 5.41 & 2.10 & 1.73 & 0.78 & 1.28 & 1.04 & 1.73 \\
\hline Total & 99.91 & 99.91 & 99.85 & 99.66 & 100.02 & 99.87 & 99.47 & 99.69 & 99.16 & 99.82 & 99.72 & 99.96 & 99.93 \\
\hline $\mathrm{Mg} \#$ & 0.64 & 0.53 & 0.55 & 0.55 & 0.55 & 0.62 & 0.82 & 0.53 & 0.52 & 0.32 & 0.35 & 0.39 & 0.39 \\
\hline \multicolumn{14}{|l|}{ in ppm } \\
\hline V & 274 & 240 & 306 & 308 & 273 & 293 & 132 & 354 & 352 & 492 & 513 & 524 & 550 \\
\hline $\mathrm{Ga}$ & 19 & 17 & 19 & 21 & 17 & 13 & 8 & 20 & 20 & 26 & 27 & 26 & 23 \\
\hline $\mathrm{Cu}$ & 50 & 20 & 45 & 36 & 59 & 45 & 58 & 154 & 134 & 202 & 211 & 323 & 170 \\
\hline $\mathrm{Zn}$ & 89 & 84 & 93 & 94 & 88 & 83 & 66 & 97 & 94 & 144 & 153 & 138 & 140 \\
\hline Co & 53 & 34 & 43 & 43 & 49 & 57 & 95 & 43 & 45 & 40 & 46 & 45 & 45 \\
\hline $\mathrm{Ni}$ & 137 & 16 & 37 & 21 & 48 & 232 & 1160 & 104 & 96 & 53 & 61 & 77 & 76 \\
\hline $\mathrm{Cr}$ & 820 & 204 & 336 & 400 & 335 & 561 & 2344 & 163 & 173 & 38.1 & 36 & 98 & 91 \\
\hline $\mathrm{Rb}$ & 30 & 17 & 35 & 43 & 6 & 5 & 5 & 27 & 14 & 13 & 11 & 10 & 8 \\
\hline $\mathrm{Ba}$ & 104 & 330 & 289 & 335 & 183 & 111 & 99 & 340 & 324 & 403 & 388 & 219 & 286 \\
\hline Th & 1.1 & 2.5 & 6.8 & 7.2 & 2.2 & 2.3 & 0.5 & 3.4 & 3.2 & 7.9 & 7.5 & 3.9 & 3.7 \\
\hline $\mathrm{U}$ & 0.2 & 0.5 & 1.4 & 1.5 & 1 & 2 & & 0.6 & 0.5 & 1.7 & 1.7 & 0.9 & 0.9 \\
\hline $\mathrm{Nb}$ & 10 & 13 & 18 & 18 & 12 & 16 & 8 & 18 & 19 & 42 & 42 & 34 & 34 \\
\hline $\mathrm{Ta}$ & 0.39 & 0.68 & 1.1 & 1.1 & 0.75 & 1 & 0.3 & 1.1 & 1.2 & 3 & 2.8 & 2.1 & 1.9 \\
\hline $\mathrm{Sr}$ & 254 & 342 & 550 & 687 & 496 & 246 & 68 & 380 & 453 & 560 & 549 & 419 & 408 \\
\hline $\mathrm{Zr}$ & 99 & 131 & 186 & 184 & 104 & 105 & 34 & 184 & 190 & 346 & 348 & 257 & 252 \\
\hline $\mathrm{Hf}$ & 2.6 & 3.7 & 5 & 4.7 & 2.7 & 2.5 & 0.85 & 5.1 & 5.2 & 10.2 & 9.4 & 6.8 & 6.4 \\
\hline $\mathrm{Y}$ & 26 & 28 & 31 & 32 & 21 & 24 & 9 & 29 & 30 & 45 & 45 & 43 & 42 \\
\hline $\mathrm{La}$ & 9.2 & 16.6 & 29.2 & 29.7 & 13.7 & 11.7 & 4.41 & 26.5 & 27.40 & 52.2 & 46.4 & 33.7 & 31.7 \\
\hline $\mathrm{Ce}$ & 22.0 & 37.3 & 74.7 & 72.6 & 35.3 & 38.5 & 10.1 & 60.9 & 61.7 & 122 & 114 & 74.4 & 68.7 \\
\hline $\mathrm{Nd}$ & 14.5 & 19.9 & 34.3 & 33.4 & 18.8 & 15.8 & 4.9 & 30.7 & 30.5 & 64.2 & 58.7 & 45 & 40.4 \\
\hline $\mathrm{Sm}$ & 3.79 & 4.98 & 6.91 & 7.21 & 4.19 & 3.93 & 1.28 & 6.69 & 6.64 & 13.1 & 12.6 & 9.79 & 8.89 \\
\hline $\mathrm{Eu}$ & 1.24 & 1.56 & 1.73 & 1.86 & 1.43 & 1.05 & 0.43 & 2.04 & 2.06 & 3.74 & 3.61 & 3.1 & 2.81 \\
\hline $\mathrm{Tb}$ & 0.67 & 0.87 & 1.08 & 1.11 & 0.73 & 0.81 & 0.30 & 0.98 & 0.96 & 1.62 & 1.58 & 1.36 & 1.23 \\
\hline $\mathrm{Yb}$ & 2.09 & 2.17 & 2.44 & 2.50 & 1.81 & 2.16 & 1.12 & 2.53 & 2.44 & 3.40 & 3.55 & 3.20 & 3.52 \\
\hline $\mathrm{Lu}$ & 0.29 & 0.33 & 0.35 & 0.36 & 0.27 & 0.33 & 0.16 & 0.29 & 0.28 & 0.5 & 0.47 & 0.46 & 0.44 \\
\hline $\mathrm{Ti} / \mathrm{Y}$ & 351 & 354 & 403 & 383 & 531 & 445 & 387 & 472 & 466 & 607 & 621 & 558 & 590 \\
\hline
\end{tabular}

EM-43 is a picrite; $\mathrm{Mg} \#=\mathrm{Mg} /\left(\mathrm{Mg}+\mathrm{Fe}^{2+}\right)$ with $\mathrm{Fe}^{3+} / \mathrm{Fe}^{2+}=0.15$.

and $\mathrm{Ba}$ relative to $\mathrm{Th}$ and $\mathrm{U}$ is observed in the HT3 lavas (Fig. 6c). They are also characterized by the significant depletion of $\mathrm{Ta}$ and $\mathrm{Nb}$ relative to $\mathrm{La}$.
Trace element distribution pattern is highly variable for the LT samples (Fig. 6d). The positive U anomaly in EM-39 and EM-41 could be due to 


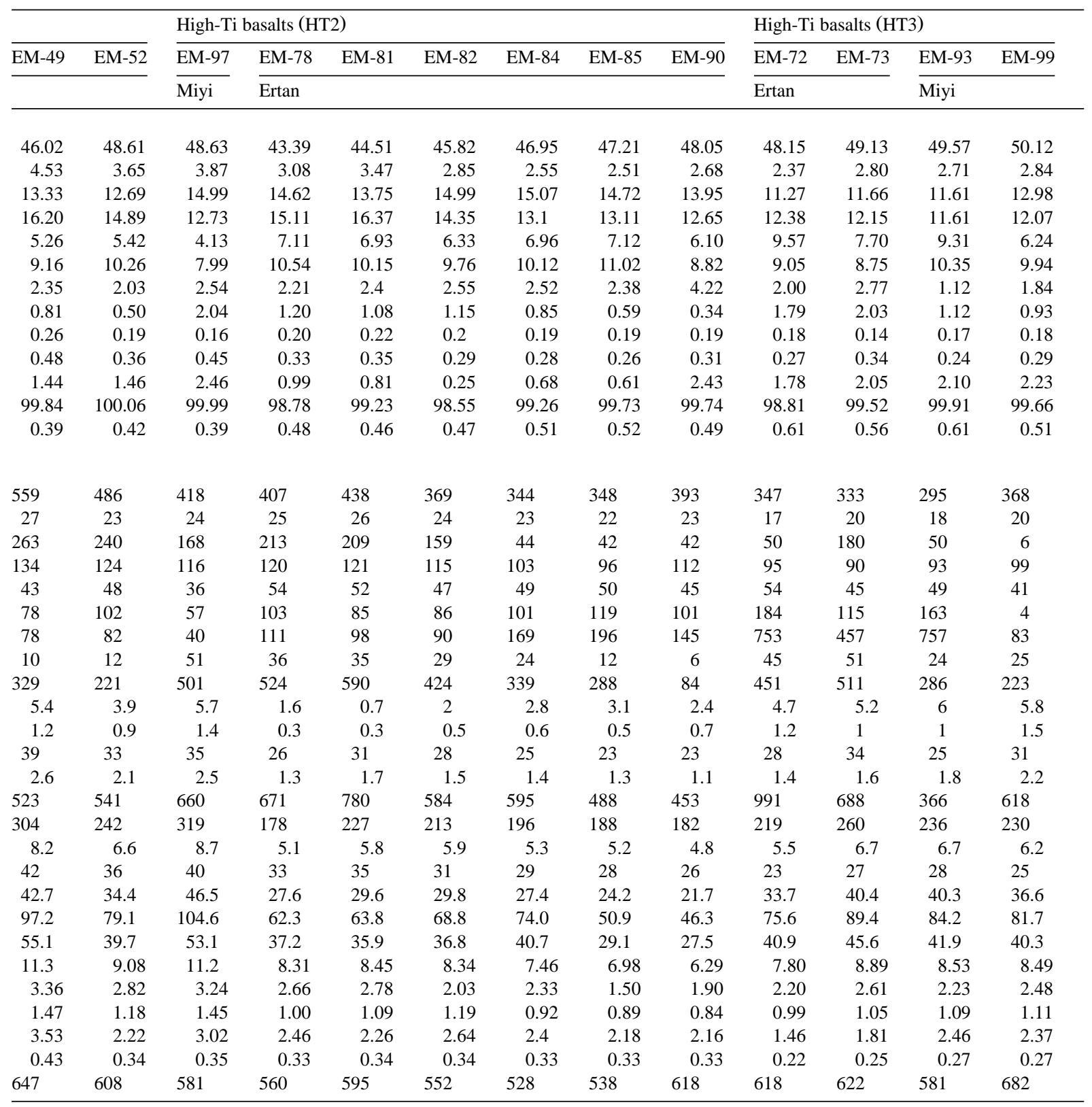

surface alteration. Some LT lavas generally show relatively low $\mathrm{Sm} / \mathrm{Yb}$ ratios compared to the $\mathrm{HT}$ samples. Samples with marked negative anomalies of
$\mathrm{Nb}$ and $\mathrm{Ta}$ (EM-35, EM-37) have significantly higher $\mathrm{Sm} / \mathrm{Yb}$ ratios than those with enrichment of $\mathrm{Nb}$ and Ta over La (EM-13, EM-41). 

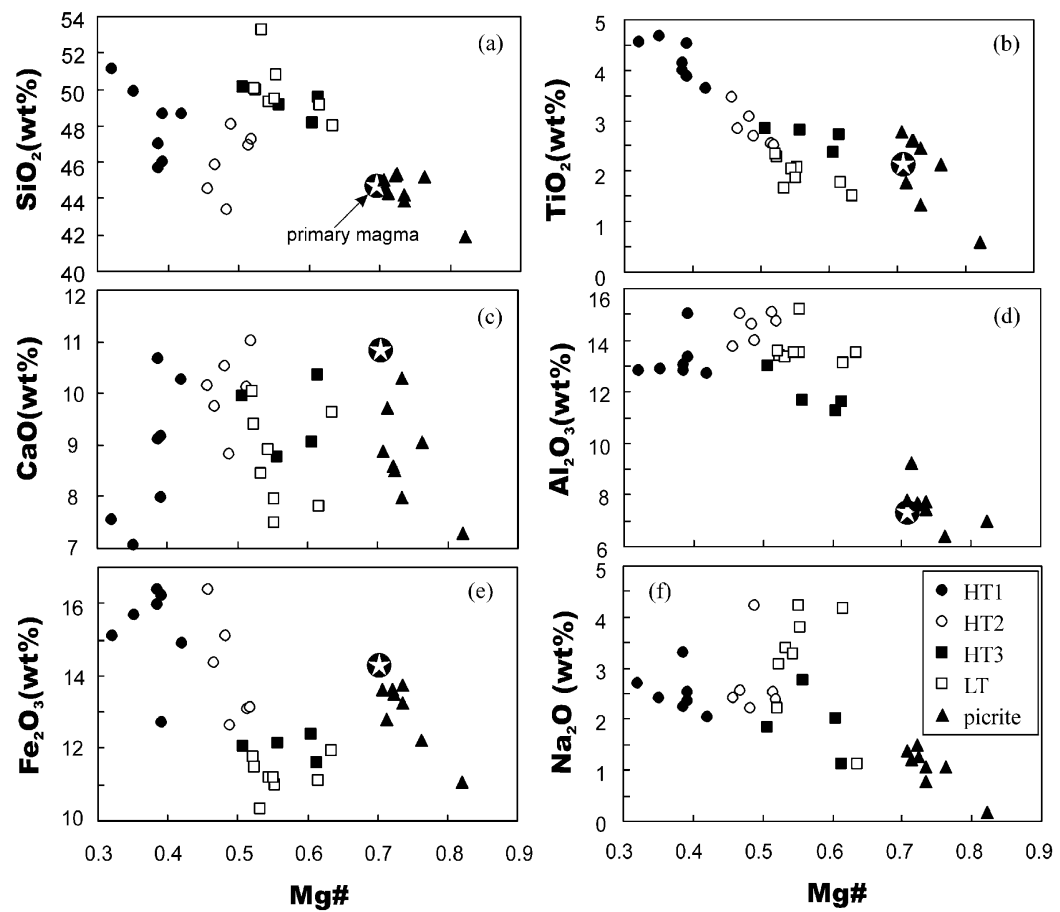

Fig. 4. Variation of $\mathrm{SiO}_{2}, \mathrm{TiO}_{2}, \mathrm{Fe}_{2} \mathrm{O}_{3}, \mathrm{CaO}, \mathrm{Al}_{2} \mathrm{O}_{3}$ and $\mathrm{Na}_{2} \mathrm{O}$ versus $\mathrm{Mg} \#$ for the Emeishan basalts. The star indicates the composition of primary magmas estimated from the composition of olivine phenocrysts in high-Ti/Y picrites and melt inclusions trapped in the olivines (Xu and Chung, 2001).

\section{5. $\mathrm{Sr}-\mathrm{Nd}$ isotope ratios}

The measured and age-corrected ${ }^{87} \mathrm{Sr} /{ }^{86} \mathrm{Sr}$ and ${ }^{143} \mathrm{Nd} /{ }^{144} \mathrm{Nd}$ ratios are listed in Table 3 . The initial isotopic ratios were all corrected to $250 \mathrm{Ma}$ according to our unpublished $\mathrm{Ar}-\mathrm{Ar}$ age data. In the ${ }^{87} \mathrm{Sr} /{ }^{86} \mathrm{Sr}(t)-\varepsilon_{\mathrm{Nd}}(t)$ correlation diagram (Fig. 7), the Emeishan basalts define an array that lies near
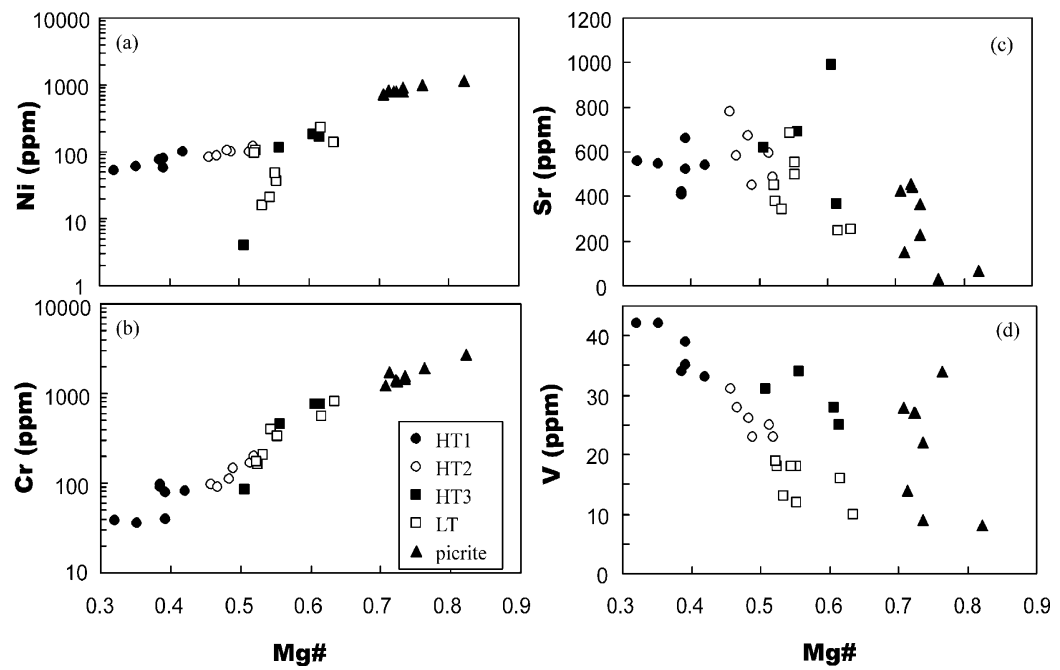

Fig. 5. Variation of $\mathrm{Ni}, \mathrm{Cr}, \mathrm{V}$ and $\mathrm{Sr}$ versus $\mathrm{Mg} \#$ for the Emeishan basalts. 

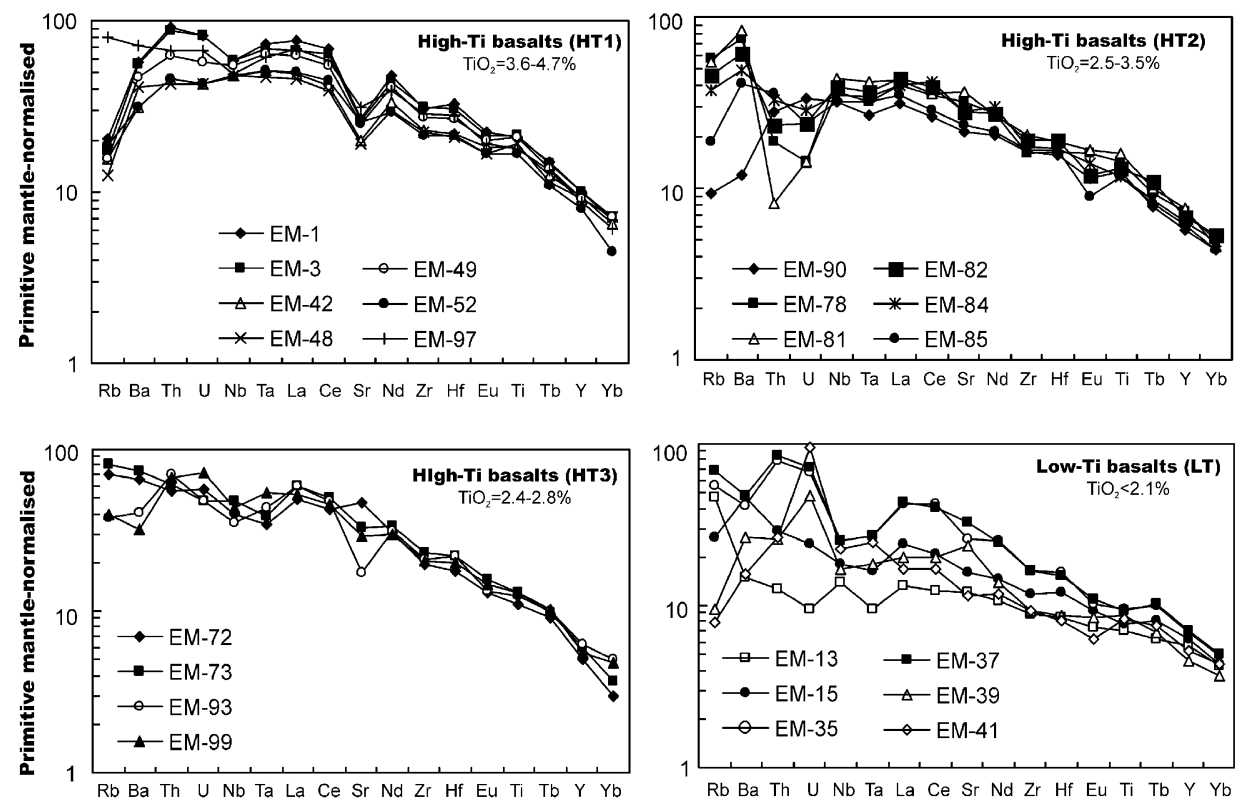

Fig. 6. Primitive mantle-normalized trace element concentrations in the Emeishan basalts. Normalizing values are from Sun and McDonough (1989).

the "mantle correlation line" but is distinctly displaced to the right. In general, the HT1 and HT2 basalts have relatively higher $\varepsilon_{\mathrm{Nd}}(t)$ and lower ${ }^{87} \mathrm{Sr} /{ }^{86} \mathrm{Sr}(t)$ values than the LT and HT3 basalts. The HT2 samples, compared to the HT1 magmas, show a remarkable limited range in $\mathrm{Sr}$ isotopic compositions (Table 3). In HT and LT magma types, the basalts that show OIB-like trace element patterns (e.g., samples EM-90, EM-42 and EM-41; Fig. 6) commonly have the highest $\varepsilon_{\mathrm{Nd}}(t)$ and lowest ${ }^{87} \mathrm{Sr} /{ }^{86} \mathrm{Sr}(t)$ (Table 3).

\section{Discussion}

Chemical variation of basaltic lavas in continental settings is essentially controlled by a number of parameters that include mantle temperature, lithospheric thickness (hence degree of partial melting), source composition, and certain shallow level processes such as crustal contamination and crystal fractionation (McKenzie and Bickle, 1988). The relative importance of these different parameters and/or processes is an important issue in the modern petrology but no consensus is reached. For example, the low-Ti and high-Ti basalts associated with the break-up of
Gondwnaland show significant difference in major, trace element composition and isotopic ratios. While Hergt et al. (1991) and Turner and Hawkesworth (1995) favor a model with different mantle sources for the two magma types, other authors (Fodor, 1987; Arndt et al., 1993) interpreted the geochemical discrepancy as a result of distinct melting condition and variable degrees of crustal contamination. We explore the key parameters/processes that govern the chemical variation of the Emeishan basalts. Focus will be given on identification of source components and the genetic relationship between the LT and HT magma types.

\subsection{Effect of alteration on magma compositions}

The Emeishan flood basalts are $\sim 250 \mathrm{Ma}$ old and have been altered to various degrees after the eruption, judged from the petrographic observation and relatively high LOI in some samples (3-4\%). This process may have changed the concentration of most incompatible elements such as $\mathrm{Rb}, \mathrm{Ba}$ and $\mathrm{K}$, because these elements are known to be mobile during surface alteration. The sign of element mobility is particularly manifested in the LT lavas which 
Table 3

$\mathrm{Rb}-\mathrm{Sr}$ and $\mathrm{Sm}-\mathrm{Nd}$ isotopic ratios and abundances for the Emeishan flood basalts

\begin{tabular}{|c|c|c|c|c|c|c|c|c|}
\hline & $\mathrm{Rb}$ (ppm) & $\mathrm{Sr}(\mathrm{ppm})$ & $\left({ }^{87} \mathrm{Sr} /{ }^{86} \mathrm{Sr}\right)_{\text {measured }}$ & $\left({ }^{87} \mathrm{Sr} /{ }^{86} \mathrm{Sr}\right)(t)$ & $\mathrm{Sm}$ (ppm) & $\mathrm{Nd}(\mathrm{ppm})$ & $\left({ }^{143} \mathrm{Nd} /{ }^{144} \mathrm{Nd}\right)_{\text {measured }}$ & $\varepsilon_{\mathrm{Nd}}(t)$ \\
\hline \multicolumn{9}{|c|}{ Low-Ti lavas (LT) } \\
\hline EM-13 & 30 & 254 & $0.707022 \pm 10$ & 0.705765 & 3.79 & 14.5 & $0.512465 \pm 5$ & -2.14 \\
\hline EM-15 & 17 & 342 & $0.706932 \pm 9$ & 0.706420 & 4.98 & 19.9 & $0.512320 \pm 6$ & -4.75 \\
\hline EM-35 & 35 & 550 & $0.706710 \pm 8$ & 0.706054 & 6.91 & 34.3 & $0.512332 \pm 5$ & -3.58 \\
\hline EM-37 & 43 & 687 & $0.706960 \pm 10$ & 0.706315 & 7.21 & 33.4 & $0.512321 \pm 6$ & -4.07 \\
\hline EM-39 & 6 & 496 & $0.705910 \pm 7$ & 0.705785 & 4.19 & 18.8 & $0.512499 \pm 6$ & -0.73 \\
\hline EM-41 & 5 & 246 & $0.705835 \pm 7$ & 0.705626 & 3.93 & 15.8 & $0.512628 \pm 12$ & 1.42 \\
\hline EM-43 & 5 & 68 & $0.705378 \pm 10$ & 0.704621 & 1.28 & 4.90 & $0.512660 \pm 4$ & 1.70 \\
\hline EM-95 & 27 & 380 & $0.705877 \pm 9$ & 0.705145 & 6.69 & 30.7 & $0.512511 \pm 6$ & -0.40 \\
\hline EM-98 & 14 & 453 & $0.705411 \pm 8$ & 0.705154 & 6.64 & 30.5 & $0.512544 \pm 5$ & 0.25 \\
\hline \multicolumn{9}{|c|}{ High-Ti lavas (HT1) } \\
\hline EM-01 & 13 & 560 & $0.706177 \pm 9$ & 0.705938 & 13.10 & 64.2 & $0.512609 \pm 6$ & 1.78 \\
\hline EM-03 & 11 & 549 & $0.706186 \pm 7$ & 0.705980 & 12.60 & 58.7 & $0.512580 \pm 5$ & 1.01 \\
\hline EM-42 & 10 & 419 & $0.704178 \pm 8$ & 0.703932 & 9.79 & 45.0 & $0.512779 \pm 5$ & 4.84 \\
\hline EM-48 & 8 & 408 & $0.704565 \pm 10$ & 0.704363 & 8.89 & 40.4 & $0.512768 \pm 5$ & 4.57 \\
\hline EM-49 & 10 & 523 & $0.704524 \pm 8$ & 0.704327 & 11.30 & 55.1 & $0.512663 \pm 5$ & 2.81 \\
\hline EM-52 & 12 & 541 & $0.704553 \pm 9$ & 0.704324 & 9.08 & 39.7 & $0.512742 \pm 10$ & 3.90 \\
\hline EM-97 & 51 & 660 & $0.705950 \pm 10$ & 0.705154 & 11.20 & 53.1 & $0.512582 \pm 5$ & 1.12 \\
\hline \multicolumn{9}{|c|}{ High-Ti lavas (HT2) } \\
\hline EM-78 & 36 & 671 & $0.705614 \pm 8$ & 0.705062 & 8.31 & 37.2 & $0.512571 \pm 5$ & 0.66 \\
\hline EM-81 & 35 & 780 & $0.705623 \pm 8$ & 0.705261 & 8.45 & 35.9 & $0.512612 \pm 5$ & 1.50 \\
\hline EM-82 & 29 & 584 & $0.705503 \pm 10$ & 0.704992 & 8.34 & 36.8 & $0.512617 \pm 5$ & 2.44 \\
\hline EM-84 & 24 & 595 & $0.705336 \pm 10$ & 0.704921 & 7.46 & 40.7 & $0.512554 \pm 3$ & 1.12 \\
\hline EM-85 & 12 & 488 & $0.705178 \pm 10$ & 0.704925 & 6.98 & 29.1 & $0.512624 \pm 5$ & 1.38 \\
\hline EM-90 & 6 & 453 & $0.704999 \pm 8$ & 0.704963 & 6.29 & 27.5 & $0.512746 \pm 5$ & 4.00 \\
\hline \multicolumn{9}{|c|}{ High-Ti lavas (HT3) } \\
\hline EM-72 & 45 & 991 & $0.706764 \pm 8$ & 0.706297 & 7.80 & 40.9 & $0.512399 \pm 4$ & -2.06 \\
\hline EM-73 & 51 & 688 & $0.707222 \pm 7$ & 0.706459 & 40.90 & 45.6 & $0.512387 \pm 5$ & -2.38 \\
\hline EM-93 & 24 & 366 & $0.708263 \pm 7$ & 0.707587 & 8.53 & 41.9 & $0.512335 \pm 8$ & -3.56 \\
\hline EM-99 & 25 & 618 & $0.706795 \pm 8$ & 0.706378 & 8.49 & 40.3 & $0.512542 \pm 10$ & 0.48 \\
\hline
\end{tabular}

${ }^{87} \mathrm{Sr} /{ }^{86} \mathrm{Sr}(t)$ and $\varepsilon_{\mathrm{Nd}}(t)$ were calculated for $250 \mathrm{Ma}$.

show considerable scatter in primitive-mantle normalized patterns. It is noted that the LT lavas have relatively higher LOI than most HT lavas (Table 2). For both HT1 and HT2 magma types, one sample is highlighted as being an exception to the overall trace element pattern shown by the majority of samples in each type (see Section 4.4). In both cases, the anomalous sample has markedly higher LOI than other samples of that magma types (i.e., HT1, EM-97; HT2, EM-90; Table 1). Clearly, the concentration of most incompatible elements in the Emeishan basalts with LOI $>2 \%$ are affected. The reasonable positive correlation between $\mathrm{Na}_{2} \mathrm{O}$ and LOI (not shown) also suggests the gain of this element during alter- ation. This casts doubt on the reliability of TAS diagram in identifying the alkaline/tholeiitic natures of the Emeishan basalts. On the other hand, age-correction of measured ${ }^{87} \mathrm{Sr} /{ }^{86} \mathrm{Sr}$ involves $\mathrm{Rb}$ concentrations. For these reasons, emphasis will be placed on immobile elements such as REE, HFSE, Th, Y and $\mathrm{Ti}$, and $\varepsilon_{\mathrm{Nd}}(t)$ in the following discussion. The discussion involving most incompatible elements and ${ }^{87} \mathrm{Sr} /{ }^{86} \mathrm{Sr}(t)$ is limited to those samples with relatively low LOI $(<2 \%)$.

\subsection{Magma fractionation}

Most basaltic lavas from the Emeishan LIP are not primary mantle melts judged from their low 


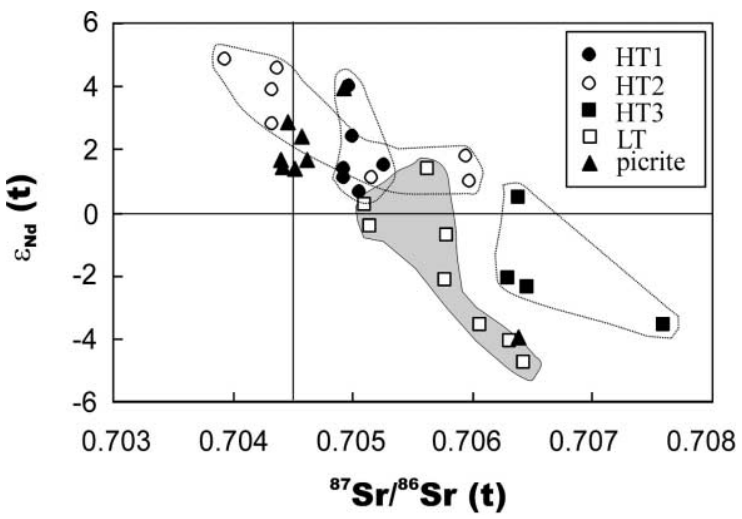

Fig. 7. Plot of initial $\varepsilon_{\mathrm{Nd}}(t)$ and ${ }^{87} \mathrm{Sr} /{ }^{86} \mathrm{Sr}(t)(t=250 \mathrm{Ma})$.

$\mathrm{MgO}$ (mostly <7\%), $\mathrm{Mg \#} \mathrm{(0.63-0.33)} \mathrm{and} \mathrm{Ni}$ contents (4-232 ppm). They are far from the expected composition of melts in equilibrium with mantle peridotites (Cox, 1980). These characteristics suggest that they underwent extensive crystal fractionation from parental magmas either in magma chambers or en route to the surface. According to Cox (1980), primary picritic magmas may have ponded and fractionated near the Moho due to the density contrast between picritic magma and crust. This process produces ultramafic cumulates and residual low $\mathrm{MgO}$ basaltic magma. A similar process may have happened at Emeishan. The high seismic velocity layer (P wave, $7.1-7.7 \mathrm{~km} / \mathrm{s}$ ) of $26 \mathrm{~km}$ in thickness at the base of the crust beneath this province (Yuan, 1989) may correspond to the underplated magmas derived from mantle plumes.

The LT lavas may have experienced fractionation of olivine (ol) and clinopyroxene (cpx) from parental magmas. This is supported by the positive correlation between $\mathrm{Ni}$ and $\mathrm{Mg \#}$ and is also consistent with the presence of cpx $( \pm \mathrm{ol})$ as the dominant phenocryst in these lavas. Because $\mathrm{Sr}$ is compatible in plagioclase, $\mathrm{Sr}$ content in the LT lavas increases as Mg\# decreases (Fig. 5) may indicate no significant fractionation of plagioclase in the magma, consistent with the absence of plagioclase phenocryst in the LT lavas. Although the fractionation process is less well constrained for the HT3 lavas due to the limited number of samples, a similar ol $+\mathrm{cpx}$ fractionation may apply to the HT3 lavas given the similar petrographic feature between HT3 and LT lavas.
The major element variation defined by the HT1 and HT2 lavas is significantly different from that of the LT lavas. Dominant plagioclase phenocrysts, the decreasing Sr with decreasing $\mathrm{Mg} \#$ and the negative $\mathrm{Sr}$ anomalies in spidergrams (Fig. 6) all suggest the importance of plagioclase over olivine in the crystal fractionation of the HT1 and HT2 basalts. The lack of a large negative $\mathrm{Eu}$ anomaly in these evolved lavas must reflect a high $\mathrm{Eu}^{3+} / \mathrm{Eu}^{2+}$ ratio in magmas (Frey et al., 1993).

In summary, there are two differentiation trends for the Emeishan basalts, with ol and cpx fractionation in the LT lavas and gabbroic $(\mathrm{cpx}+$ plag $\pm \mathrm{ol})$ fractionation in the HT basalts. Ti-Fe oxides do not appear to be the major fractionation mineral given the negative correlation between $\mathrm{Fe}$ and $\mathrm{Ti}$ and $\mathrm{Mg \#}$ (Fig. 4b,e). An important question remains as to whether the LT and HT lavas represent fractional products of a common parental magma. Using composition of olivine phenocrysts in high-Ti/Y picrites and melt inclusions trapped in the olivines, $\mathrm{Xu}$ and Chung (2001) estimated the composition of parental magma of the picrites, which is plotted in Fig. 4. It is clear that the high- $\mathrm{Ti} / \mathrm{Y}$ picrites are not parental magma to the LT lavas. The low-Ti/Y picrite (EM43) reported in this study provides an alternative for the parental magma to the LT lavas. Although it deserves further assessment, the genetic link between them can be established because this picrite and the least-contaminated LT sample have similar Ti/Y, $\mathrm{Nb} / \mathrm{La}$ and $\varepsilon_{\mathrm{Nd}}(t)$ (Table 4). The similarity in trace element ratio and $\varepsilon_{\mathrm{Nd}}(t)$ between the least-contaminated HT1-HT2 lavas and high-Ti/Y picrites (Table 4) suggests that the high-Ti picrite may be parental magmas to the HT1 and HT2 lavas. This implies no simple fractionation relationship between the LT and HT lavas. It is therefore possible that HT and LT lavas may have evolved from respective

Table 4

Comparison of selected trace element ratios and $\varepsilon_{\mathrm{Nd}}$ between least-contaminated high-Ti picrites and basalts, and low-Ti picrites and basalts

\begin{tabular}{lllll}
\hline & $\varepsilon_{\mathrm{Nd}}(t)$ & $\mathrm{Nb} / \mathrm{La}$ & $\mathrm{Ti} / \mathrm{Y}$ & $\mathrm{Zr} / \mathrm{Nb}$ \\
\hline High-Ti picrite & 4.0 & $1-1.1$ & $505-610$ & 8 \\
High-Ti basalt & $4.6-4.8$ & $1-1.1$ & $560-590$ & $7.3-7.8$ \\
Low-Ti picrite & 1.7 & 1.8 & 387 & 6.6 \\
Low-Ti basalt & 1.4 & 1.4 & 445 & 4.3 \\
\hline
\end{tabular}


parental magmas. Other evidences for this argument include: (1) some HT2 lavas have significantly lower $\mathrm{SiO}_{2}$ content than the LT lavas at comparable $\mathrm{Mg \#}$ (Fig. 5); (2) Field observation reveals that the LT and HT lavas are both temporally and spatially decoupled. In the west part of the Emeishan LIP, the HT lavas generally overlay the LT lavas. No LT lavas have been documented in east part of province; (3) The least-contaminated LT and HT show different isotopic composition (Table 4). The HT3 lavas show compositional variation that is not coherent with other basalts from the Emeishan LIP. They could have been derived from another independent mantle source. It appears, therefore, that there was a variety of parental magmas for the Emeishan basalts. In the next section, melting conditions of dominant HT1, HT2 and LT lavas will be discussed.

\subsection{Melting conditions and source characteristics}

\subsubsection{Major element constraints}

In order to evaluate chemical signatures deriving from melt generation in continental LIPs, the effects of fractional crystallization on chemical composition must be removed first. Here we adopted the approach proposed by Klein and Langmuir (1987) to extrapolate the evolved composition back to $8 \mathrm{wt} . \%$ $\mathrm{MgO}$ using best-fit linear regression. Using this approach, Klein and Langmuir (1987) first identified the global trends of MORB and interpreted them in terms of parameters such as pressure/temperature and degree of partial melting. This approach has been widely applied to the CFB petrogenesis studies and yielded important information about melting conditions and source characteristics (Hergt et al., 1991; Turner and Hawkesworth, 1995; Garland et al., 1996; Lassiter and Depaolo, 1997).

Correction of major element compositions of the Emeishan flood basalts at a constant $\mathrm{MgO}$ of $8 \%$ has been carried out using the best fitted linear lines for the HT1 and HT2, and LT magmas, respectively. All samples were used to calculate a regression line but only samples with $>5 \% \mathrm{MgO}$ were used. The HT and LT magmas define distinct positions in Fig. 8. The LT lavas have higher $\mathrm{Si}_{8}$ and lower $\mathrm{Fe}_{8}$ than the HT1 and HT2 lavas. $\mathrm{Si}_{8}$ abundance in primitive melts is negatively correlated with the pressure of

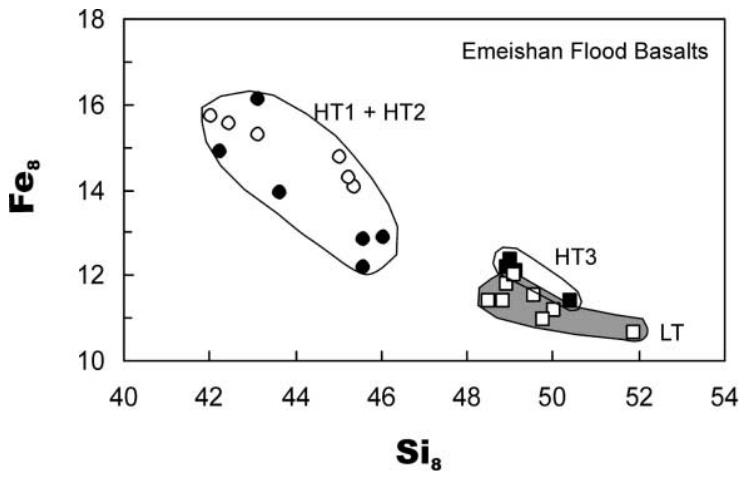

Fig. 8. $\mathrm{Si}_{8}$ versus $\mathrm{Fe}_{8} . \mathrm{Si}_{8}$ and $\mathrm{Fe}_{8}$ are the calculated $\mathrm{SiO}_{2}$ and $\mathrm{Fe}_{2} \mathrm{O}_{3}$ concentrations for a $\mathrm{MgO}$ content of $8 \%$.

melt generation (Garland et al., 1996). Experimental data shows that $\mathrm{Fe}$ content in primitive magmas is strongly influenced by the pressure of melt generation with Fe contents in melt being positively correlated with pressure (Hirose and Kushiro, 1993). Accordingly, the HT1 and HT2 lavas may have been generated at a higher pressure than the LT basalts. However, different melting condition is not the unique interpretation for the compositional distinction between the HT1-HT2 lavas and LT samples. Lithospheric mantle is likely to be more refractory on average than the underlying convective mantle. Thus, melt generation from refractory mantle source can lower $\mathrm{Fe}_{8}$. The relatively high $\mathrm{Fe}_{8}(12-16 \%)$ suggests that the HT1 and HT2 lavas from Emeishan were mainly produced from fertile mantle with anomalously high potential temperature. In contrast, the LT and HT3 lavas may result from melting of a depleted mantle source (e.g., Turner and Hawkesworth, 1995). Alternatively, the relatively low $\mathrm{Fe}_{8}$ content may be due to crustal contamination, because crustal contamination in general lowers the $\mathrm{Fe}_{8}$ contents of a suite of lavas (Peng et al., 1994). The distinction between these alternatives is not straightforward and will be addressed in next sections.

\subsubsection{Constraint from REE composition}

REE in basalts have been demonstrated to be very sensitive to the amounts of extension and lithospheric thickness (McKenzie and O'Nions, 1991; Ellam, 1992; Kerr, 1994). Low $\mathrm{Ce} / \mathrm{Yb}$ ratios in basalts reflect melting regimes dominated by rela- 
tively large melting fractions and/or spinel as the predominant residual phase (thin lithosphere), whereas high $\mathrm{Ce} / \mathrm{Yb}$ ratios correspond to smaller melt fractions and/or garnet control (thick lithosphere). Following these reasoning, the variation of light REE enrichments observed in the Emeishan basalts can be explained by the change of lithospheric thickness. The LT basalts were generated within spinel-garnet stability, at a depth less than 70 $\mathrm{km}$. In contrast, the depth of melting for the HT magmas is well within the garnet stability $(>80$ $\mathrm{km}$ ). This is qualitatively consistent with the evaluation in terms of major element composition.

To quantitatively determine the melting conditions, we adopt the fractional melting inversion of McKenzie and O'Nions (1991), incorporating the modification proposed by White et al. (1992). The inversion utilizes averaged REE concentrations to estimate the melt distribution as a function of depth, the total integrated melt fraction, and the total melt thickness, equivalent to the thickness of basaltic crust produced. Only samples with $\mathrm{MgO}>6$ wt.\% were used in REE inversion to minimize the effect of fractionation. Because all HT1 samples have $\mathrm{MgO}$ $<6 \%$, the HT2 lavas were consequently used in REE inversion for the HT magma type. For the LT magma type, the samples with high $\mathrm{Sm} / \mathrm{Yb}$ may have been affected by lithospheric contamination, thus only those with low $\mathrm{Sm} / \mathrm{Yb}$ were used. The inversions were run assuming that the garnet-spinel transition occurs between 80 and $100 \mathrm{~km}$, equivalent to a mantle potential temperature of $1500{ }^{\circ} \mathrm{C}$. The source producing the best fit of the LT basalts is MORB mantle source enriched by small melt frac-
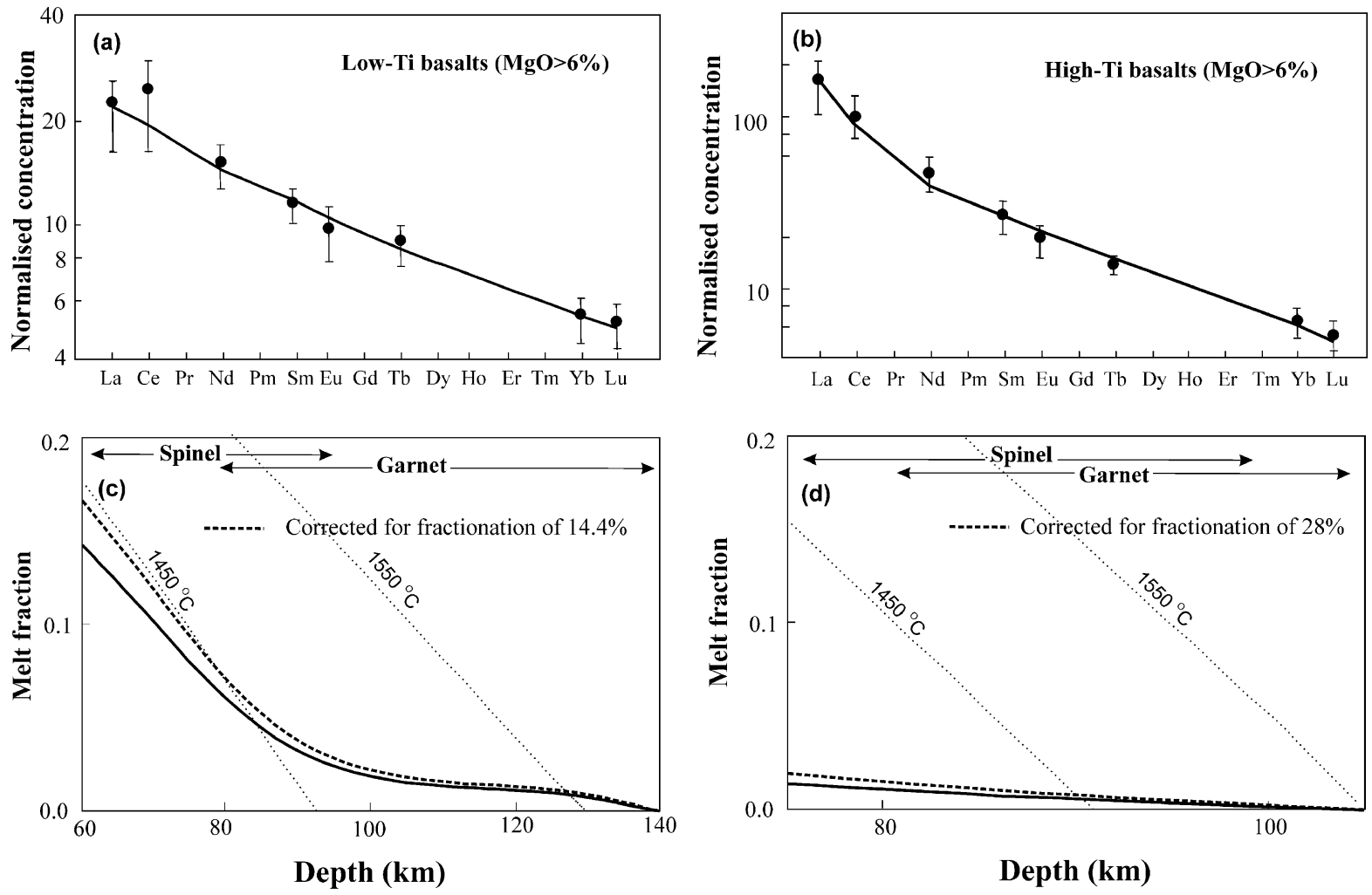

Fig. 9. (a,b) Observed and calculated rare-earth element concentrations, normalized to bulk earth for the Emeishan LT and HT basalts with $\mathrm{MgO}>6$ wt.\%. Mean values for each element are shown by dots. Vertical bars illustrate one standard deviation, estimated from the variance of the data. The heavy line shows the best fit to the data obtained by fractional melting inversion. (c,d) Melt distribution for the Emeishan basalts estimated from REE inversion. Thin dashed line with labeled temperatures is the predicted melt distribution from isentropic decompression of mantle (White and McKenzie, 1995). 
tion derived from a depleted mantle. The HT2 lavas show positive $\varepsilon_{\mathrm{Nd}}(t)$ suggesting that they were primarily generated within the asthenosphere and was then modeled by simple one-stage melting of mantle.

Fig. 9a shows the comparison between observed mean concentration for the LT basalts from the Emeishan LIP, and the best fit to the data obtained by inversion. The fit is rather good for all REE, well within the error bars. Fig. 9c shows the melt distribution required to produce this fit, with dashed line illustrating the inferred original melt distribution after correction for $14.4 \%$ fractionation. The comparison between the melt distributions inferred from the LT lavas and the predicted one from isentropic decompression of mantle indicates a mantle potential temperature of $>1550{ }^{\circ} \mathrm{C}$. The melt distributions also show melting starting at a depth of $140 \mathrm{~km}$. The upper limit of melting in the inversion is $60 \mathrm{~km}$, typical of basalts generated beneath stretched and thinned continental lithosphere. The maximum melt fraction estimated from inversion is of about $16 \%$ and the total melt thickness after fractionation correction is nearly $5 \mathrm{~km}$. The estimated thickness is significantly greater than the observed thickness of the LT lavas (presumably $\sim 3 \mathrm{~km}$ ). Neither erosion nor lateral flow can account for this discrepancy. Melt may have been trapped around the Moho or in the lowermost part of crust, as suggested by the high seismic velocity layer below the Moho in this region (Yuan, 1989). In contrast, the maximum melt fraction estimated from inversion of the HT lavas is significantly low (1.5\%, Fig. 9d) and the total melt thickness after fractionation correction is only 500 $\mathrm{m}$. The melting starts at $\sim 100 \mathrm{~km}$ and the upper limit of melting in the inversion is $75 \mathrm{~km}$. These results suggest that the HT lavas were generated at a higher depth by a smaller degree of partial melting from mantle than the LT lavas. The potential temperature of the mantle involved in melt generation of the HT lavas is also relatively lower $\left(<1500{ }^{\circ} \mathrm{C}\right)$ compared to that for the LT lavas. Therefore, any transition from the LT to HT lavas is believed to be associated with change in melting conditions.

\subsection{Plume signature in the Emeishan basalts}

A starting plume model has been put forward for the generation of the Emeishan basalts by Chung et al. (1998) mainly based on two arguments. (1) The immense volume of magma produced in a rather short time span requires a large thermal anomaly within the mantle. (2) Forsterite (Fo) contents in olivine phenocrysts in picrites vary from 83 to 89 (Xu and Chung, 2001). This indicates various amounts of accumulated olivines in the Emeishan picrites and primary magmas have $\mathrm{MgO}$ of $14-16 \%$. The presence of high magnesian lavas suggests a mantle hotter than the ambient mantle (McKenzie and Bickle, 1988; Campbell and Griffiths, 1990). The high potential temperature $\left(>1550{ }^{\circ} \mathrm{C}\right)$ is also revealed by the REE inversion results presented in this study. Here, we reinforce the plume model by providing the compositional evidence, which is not equivocal for some important CFBs (e.g., Parana, Peate, 1997; Karoo, Ellam and Cox, 1991).

Most HT1 and HT2 samples exhibit the trace element ratios that overlap with the field of oceanic island basalts (OIB) (Fig. 10a). They show smooth trace element patterns that are very similar to OIB except for weak $\mathrm{Nb}$ anomaly in some samples. The pronounced negative $\mathrm{Sr}$ anomaly in HT1 lavas suggests that they have been affected by extensive fractionation of plagioclase. Samples with low trace element abundance (e.g., EM-42, EM-48) also show high $\varepsilon_{\mathrm{Nd}}(t)(4.6-4.8)$ and low ${ }^{87} \mathrm{Sr} /{ }^{86} \mathrm{Sr}(t)$ (0.7042-0.7046) values, thus likely reflecting the isotopic signature of the least-contaminated Emeishan plume head. A similar $\mathrm{Sr}-\mathrm{Nd}$ isotopic composition of the plume head has also been proposed on the basis of analyses of the high-Ti/Y picritic lavas (Chung and Jahn, 1995). This indicates a depleted mantle source for the HT1 and HT2 lavas, consistent with the relative depletion of $\mathrm{Rb}$ and $\mathrm{Ba}$ compared with Th, Ta and La in the HT1 samples (Fig. 6a). As was shown by Hofmann (1988), the "hump-shape" in the trace element pattern is a source feature and can be explained by remelting of source that had been depleted in highly incompatible elements through earlier melt extraction.

Although isotopic composition of most LT lavas can be accounted for by contamination of this same plume component $\left[\varepsilon_{\mathrm{Nd}}(t) \sim+5\right.$ and ${ }^{87} \mathrm{Sr} /{ }^{86} \mathrm{Sr}(t)$ $\sim 0.704$ ] by upper crust or CLM (continental lithospheric mantle) components, several lines of evidence suggest the possible involvement of another plume component in the generation of the LT lavas. 

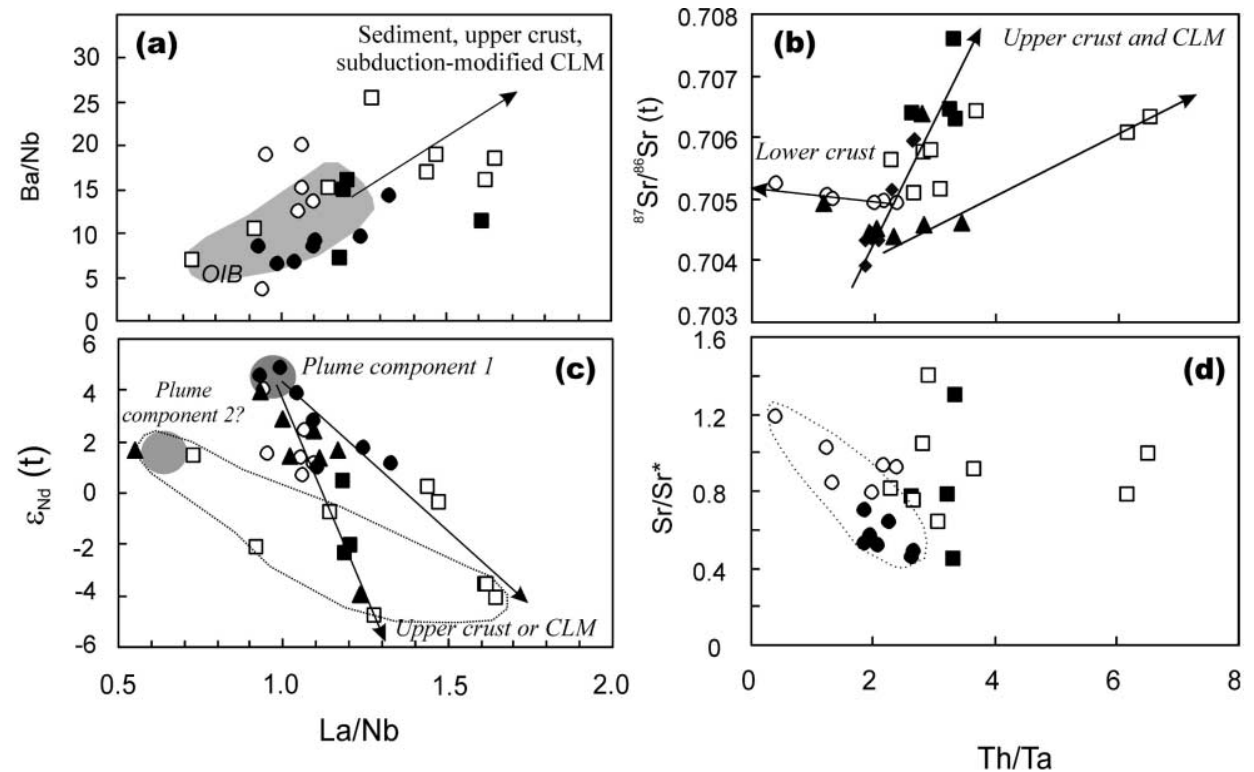

Fig. 10. (a) Ba/Nb vs. La/Nb; (b) ${ }^{87} \mathrm{Sr} /{ }^{86} \mathrm{Sr}(t)$ vs. Th/Ta; (c) $\varepsilon_{\mathrm{Nd}}(t)$ vs. La/Nb and (d) $\mathrm{Sr}_{\mathrm{N}} / \mathrm{Sr}_{\mathrm{N}}^{*}$ vs. Th/Ta diagrams for the Emeishan flood basalts. $\mathrm{Sr}_{\mathrm{N}}^{*}=\left(\mathrm{Ce}_{\mathrm{N}}+\mathrm{Nd}_{\mathrm{N}}\right) / 2$. $\mathrm{N}$ stands for chondrite normalization. The field of OIB is after Weaver (1991) and Sun and McDonough (1989).

The least-contaminated LT lava (EM-41) shows a smooth trace element pattern and OIB-like trace element ratios. Its $\varepsilon_{\mathrm{Nd}}(t)$ value of 1.4 is also the highest among the LT lavas. Similar isotopic composition is observed in low-Ti/Y picrite (EM-43) [e.g., $\left.\varepsilon_{\mathrm{Nd}}(t)=1.7\right]$. It should be noted that the isotopic composition of these least-contaminated LT lavas is different from that identified on the basis of geochemistry of HT lavas (Table 4). Moreover, Fig. 10c shows that a component with composition similar to that of EM-41 is required to account for the geochemical variation of a number of LT samples. Despite the limited data, we propose that the leastcontaminated LT magmas probably originated from a mantle source region distinct from that for the HT lavas. Whether this second source is related to the heterogeneity of the Emeishan plume or entrainment of an "exotic" component in the plume head remains to be clarified.

\subsection{Lithospheric signature: CLM or crustal contam- ination?}

Some LT and HT lavas show negative $\mathrm{Nb}$ anomaly suggesting that components other than plume must have been involved in generation and evolution of the Emeishan basalts. The most likely components are from lithosphere. There is still a hot debate about the way by which the lithosphere contributes to magma generation. Either contamination of plume magmas by lithosphere-derived melts (Arndt et al., 1993) or whole-scale melting of the subcontinental lithospheric mantle (CLM, Gallagher and Hawkesworth, 1992) has been proposed.

As discussed previously, the HT1 and HT2 basalts have undergone the gabbroic fractionation. This process should buffer $\mathrm{SiO}_{2}$ with decreasing $\mathrm{MgO}$ contents (Cox, 1980). The increasing $\mathrm{SiO}_{2}$ contents with decreasing $\mathrm{MgO}$ for both $\mathrm{LT}$ and $\mathrm{HT}$ lavas are suggestive of input of high $\mathrm{Si}$ crustal materials. An increase in ${ }^{87} \mathrm{Sr} /{ }^{86} \mathrm{Sr}(t)$ and decrease in $\varepsilon_{\mathrm{Nd}}(t)$ with increasing $\mathrm{SiO}_{2}$ for the HT1 samples (Fig. 11) indicate an AFC (assimilation and fractional crystallization, DePaolo, 1981) style of contamination. The presence of plagioclase phenocrysts in the HT samples suggests that the fractionation took place at pressure less than $10 \mathrm{kbar}$ (Stolper, 1980). Most HT lavas thus may have experienced plagioclase fractionation in a crustal magma chamber. This pre- 

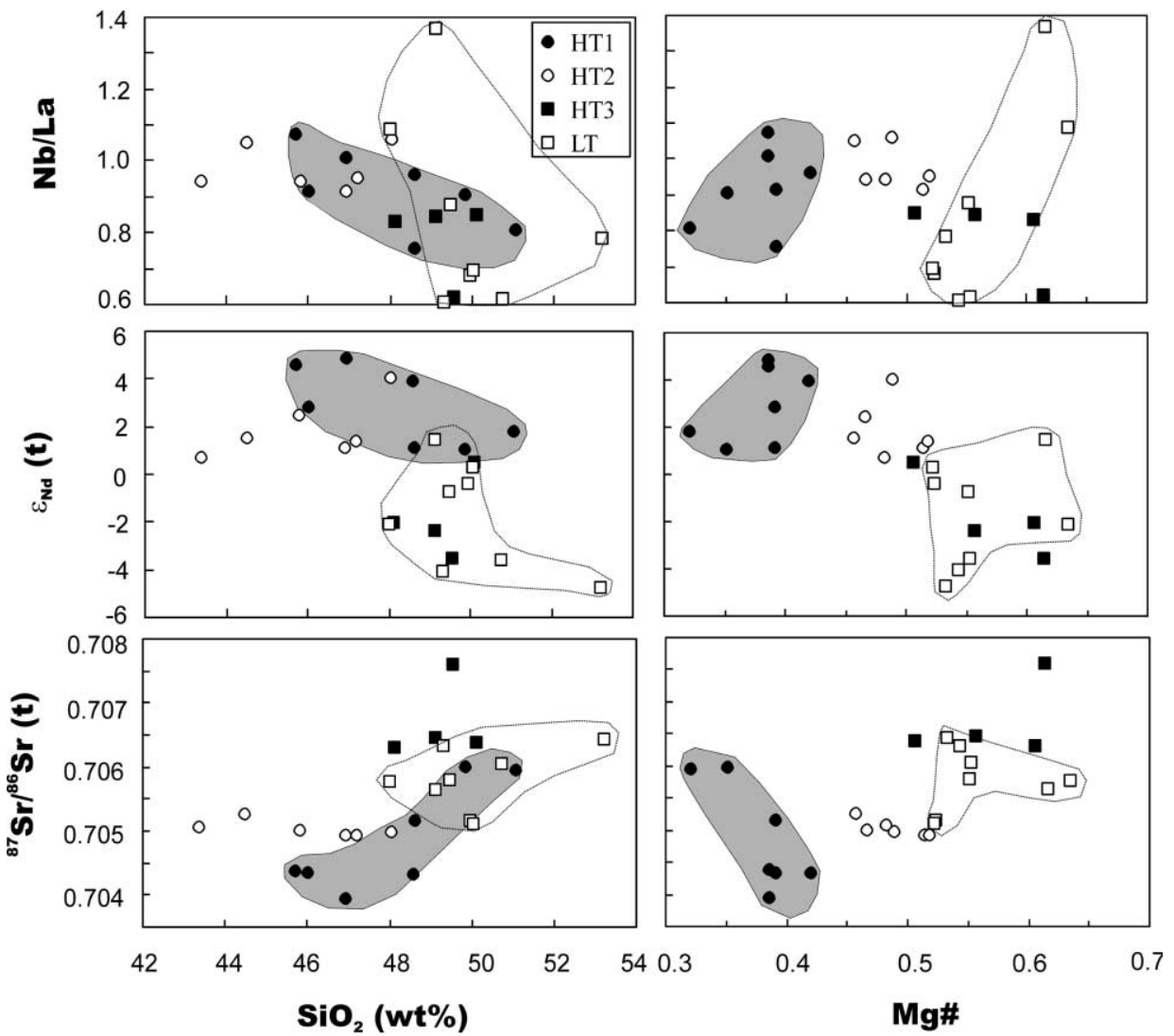

Fig. 11. Plots of $\mathrm{Nb} / \mathrm{La}, \varepsilon_{\mathrm{Nd}}(t)$ and ${ }^{87} \mathrm{Sr} /{ }^{86} \mathrm{Sr}(t)$ against $\mathrm{SiO}_{2}$ and $\mathrm{Mg}$. The trends defined by the HT1 lavas (shaded areas) are consistent with the AFC style of contamination.

cludes the possibility of lamproitic melts derived from enriched CLM as a contaminant of the HT1 and HT2 lavas (e.g., Ellam and Cox, 1991).

HT2 and HT1 lavas may share a similar plume source because the least-contaminated lavas show similar isotopic composition. However, in Figs. 10 and 11, the HT2 basalts forms a distinct trend suggesting a different magma plumbing system from the HT1 basalts. These lavas contain abundant plagioclase phenocrysts. The negative Eu anomaly suggests that they are not plagioclase-rich cumulates, but may have experienced some degree of plagioclase fractionation. It is noted that the diagnostic of plagioclase fractionation in the HT2 lavas (negative Eu anomaly, no obvious $\mathrm{Sr}$ anomaly) is different from that in the HT1 samples (pronounced negative $\mathrm{Sr}$ anomaly and no Eu anomaly). Although this discrepancy can be accounted for in terms of different oxygen fugacity, it is likely that the HT2 lavas contain a component derived from plagioclase-rich gabbros. This suggestion is supported by negative U-Th anomalies (Fig. 6). Similar U-Th depletion has been documented in Hawaii shield lavas and has been interpreted as evidence for recycled plagioclase-rich oceanic gabbros in the magma sources (Hofmann and Jochum, 1996). Layered gabbro intrusions are widespread in the Emeishan LIP. Preliminary analyses do reveal characteristic Th deficiency relative to $\mathrm{Ba}$ and $\mathrm{La}$ in these gabbros (Chung et al., unpublished data). We therefore interpret the HT2 lavas as mixtures involving plume-derived magmas and melts derived from gabbros. A possible scenario 
is that the plume-derived magmas rose through the crust-mantle boundary and induced the melting of the gabbros that emplaced at a previous time. Mixing with melts derived from gabbros is expected to mitigate the strong $\mathrm{Sr}$ depletion in the original HT2 magmas and result in strong Th depletion. This is consistent with the negative correlation between $\mathrm{Th} / \mathrm{Ta}$ and $\mathrm{Sr}_{\mathrm{N}} / \mathrm{Sr}_{\mathrm{N}}^{*}\left[\mathrm{Sr}_{\mathrm{N}}^{*}=\left(\mathrm{Ce}_{\mathrm{N}}+\mathrm{Nd}_{\mathrm{N}}\right) / 2\right]$ for the HT2 and HT1 lavas (Fig. 10d). For instance, the positive $\mathrm{Sr}$ anomaly is observed in the sample with the lowest Th content (i.e., EM-81).

AFC trend is less evident for the LT samples. This has been taken as evidence by many authors against crustal contamination being the primary control on isotopic variation in CFBs. The chemical and isotopic composition of the LT samples may inherit that of the CLM. However, the thickness of the LT lavas in the Emeishan LIP is more than $3000 \mathrm{~m}$. These lavas were emplaced during a relatively short time span (Chung et al., 1998; Huang and Opdyke, 1998). It is thus difficult to imagine that such a large volume magma was generated by melting of lithospheric mantle which is stable for a long time period in a nonconvective state. The thermomechanic model suggests that only a small amount of melts can be produced from the lithospheric mantle by conduction of heat from mantle plume (McKenzie and Bickle, 1988; Arndt and Christensen, 1992). The generation of the large amount of CFB is likely confined to the convective asthenosphere or plume. It has been argued that the melting temperature of the lithosphere may be considerably reduced by the presence of volatile phases and melting of hydrous CLM would be more readily than the volatile-free plume (Gallagher and Hawkesworth, 1992). If this model applies to the Emeishan LIP, the LT lavas should be hydrous. However, primary biotites are only found in some HT2 lavas but not in the LT samples (Table 1). While one can argue that the presence or absence of hydrous phases is also dependent on temperature of basaltic lavas, the OIB-like signature in some leastcontaminated LT lavas strongly suggests that the parental magma of the LT lavas was derived from the convective mantle. The geochemical variation of the LT lavas can therefore be accounted for by mixing between the plume and lithospheric components. There are many reasons to account for the scattered contamination trajectories of the LT sam- ples. (1) It has been shown that plagioclase crystallization, or its absence, has a distinctive impact on AFC trajectories (DePaolo, 1981). The plagioclase fractionation has played an important role in the evolution of the HT lavas, but not in the LT lavas. (2) The LT samples come from a wide range of stratigraphic positions and are unlikely to represent the products of a single magmatic plumbing system. (3) The lithosphere (crust + CLM) in the western Yangtze cration is extremely heterogeneous. The scattered data of LT samples in Fig. 11 may reflect the combined effect of the contamination by the upper crust and by components derived from the heterogeneous CLM (Fig. 10c).

The chemical variation of the Emeishan basalts cannot be reconciled with contamination of a common magma, given the incoherent chemical variation between LT and HT lavas in Fig. 11. This again requires various parental magmas. Moreover, the high ${ }^{87} \mathrm{Sr} /{ }^{86} \mathrm{Sr}(t)$ and low $\varepsilon_{\mathrm{Nd}}(t)$ in less fractionated samples (Fig. 11) is not consistent with a simple AFC process within a magma chamber. This instead reflects a temperature-controlled style of contamination where hot high-MgO basalts rapidly assimilate crustal rocks without fractionating substantially (Huppert and Sparks, 1985). It is likely that the LT magmas experienced two stages of contamination: the LT lavas assimilated crustal materials during ascent through conduits, and then have undergone an AFC style of contamination within a magma chamber prior to eruption.

Contamination appears to have played a more important role in the LT lavas than in the HT lavas. Because the LT lavas are overlain by the HT lavas, it can be inferred that contamination of plume-derived magma decreases with time (also see Fig. 12). This could result from the decreasing assimilation of the wall-rock in conduit systems over time as successive eruptions gradually depleted available contamination material. The earlier magmas would be the most contaminated owing to disruption and erosion of wall-rock during formation of the magmatic chamber. As these were erupted and the conduits are coated by replenished fresh magmas, the degree of contamination tends to decrease with time. This is the scenario likely happened in the Emeishan LIP, because the least-contaminated LT lavas are located above the contaminated LT basalts (Fig. 12) and 


\section{(a) Binchuan}

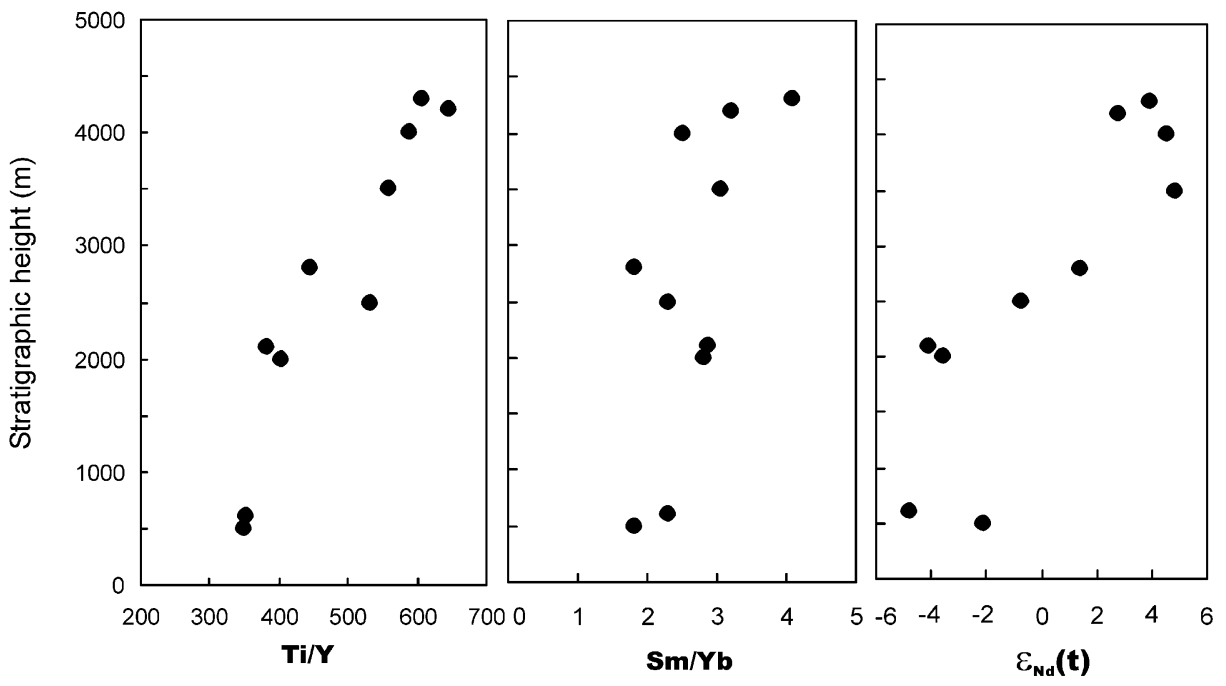

(b) Ertan

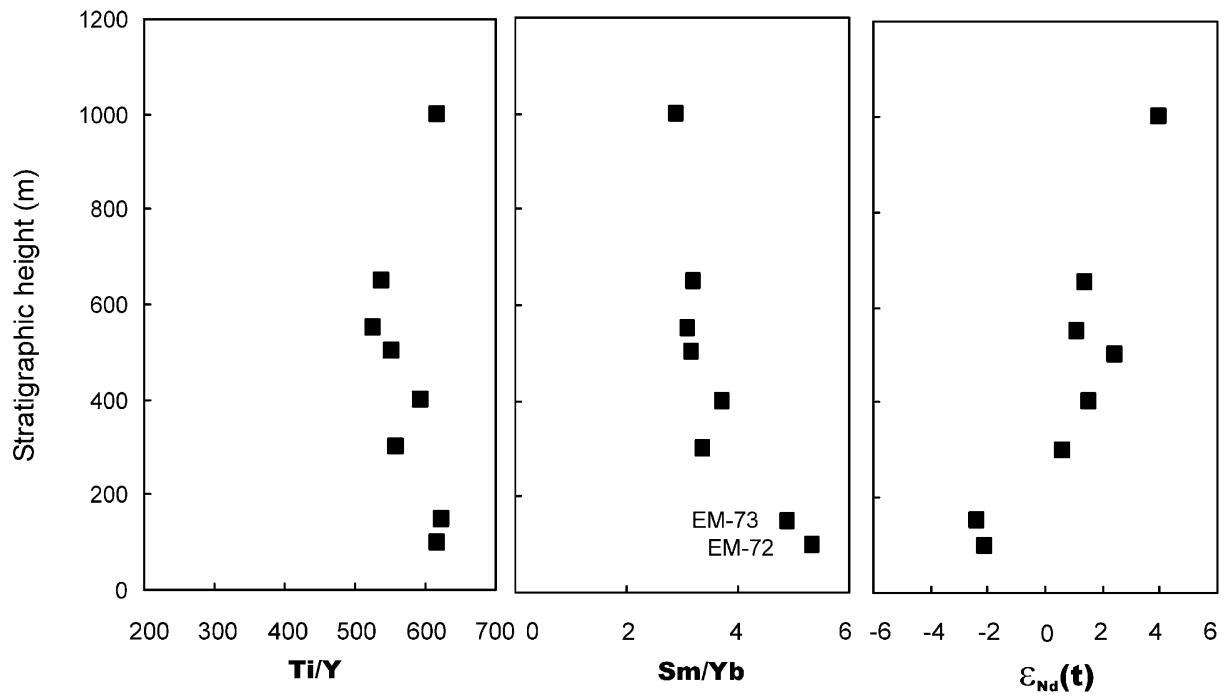

Fig. 12. Variation in $\mathrm{Ti} / \mathrm{Y}, \varepsilon_{\mathrm{Nd}}(t)$ and $\mathrm{Sm} / \mathrm{Yb}$ in the Emeishan basalts with stratigraphic height.

evolved rhyolites at the top of lava section typically have high $\varepsilon_{\mathrm{Nd}}(t)$ ( $>2$, Chung et al., unpublished data).

\section{Remarks on temporal and spatial relationships between the HT and LT lavas}

The temporal and spatial relationship between the LT and HT lavas in the Emeishan LIP is necessary to address, because it is critically important in understanding the thermal structure of the Emeishan plume and the nature of the plume-lithosphere interaction. Fig. 12 illustrates some general stratigraphic variations for several key geochemical parameters in Binchuan and Ertan. At Binchuan, $\mathrm{Ti} / \mathrm{Y}, \mathrm{Sm} / \mathrm{Yb}$ and $\varepsilon_{\mathrm{Nd}}(t)$ increase with increasing stratigraphic height. The lavas from the lower sequence show more lithospheric signature, whereas the samples 
from the upper sequence display more asthenospheric affinity. This temporal shift from lithospheric to asthenosphere signature has been documented in many CFBs (White and McKenzie, 1995) and is commonly attributed to the variation in source (e.g., Garland et al., 1996; Lassiter and Depaolo, 1997). As shown in the Siberian traps and many other CFBs, the CLM component is commonly encountered in those early erupted voluminously insignificant alkali basalts (see review of Lassiter and Depaolo, 1997). However, in the Emeishan LIP, the volume of the LT lavas with lithospheric signature is much greater than that of the HT lavas that are dominated by plume signature. As such, lithospheric signature observed in the Emeishan basalts may be derived from crust and/or CLM contamination rather than source characteristics.

The increase in $\mathrm{Sm} / \mathrm{Yb}$ with increasing stratigraphic height at Binchuan is the reverse of that observed in other $\mathrm{CFBs}$ where $\mathrm{Sm} / \mathrm{Yb}$ in basalts decreases with time (e.g., Wooden et al., 1993; Kerr, 1994). As summarized by Lassiter and Depaolo (1997), the temporal increase in melt fraction and decrease in depth of melting is a common feature of many CFBs, and is expected if melt generation is due to the interaction of a mantle plume with thinning lithosphere (White and McKenzie, 1995). The discrepancy between the temporal chemical variation in Emeishan LIP and other CFBs may be due to the lack of systematic sampling, especially of the early phase of volcanism. The recent investigation of lava flows in the Maymecha River basin in the Siberian trap (Arndt et al., 1998) sheds light on this problem. The lower part of sequence in the Maymecha River basin shows a transition from volumetrically small alkaline basalts to dominant, monotonous tholeiitic basalts, corresponding to that found in the classic Noril'sk section. The tholeiitic basalt is succeeded by compositionally diverse rocks including trachybasalt, nephelinite, picrite and meymechite (Arndt et al., 1998). It is interesting to note that the lithological and chemical variations in the upper part of the Maymecha River section are strikingly similar to what observed at Binchuan. Moreover, two mantle sources and two plumbing systems are suggested by Arndt et al. (1998) to account for the compositional distinction between tholeiitic and alkaline suites from the Maymecha River basin. Similar petrogenesis can be applied to the HT and LT lavas in the Emeishan LIP (see above). Compared to the stratigraphic variation for lavas of the Maymecha River basin, it is likely that the Binchuan section represents the middle to upper part of the entire lava succession of the Emeishan LIP. The geodynamic process associated with the variation from the LT to HT lavas could be related to the transition from the peak to the waning stage of the mantle plume activity.

Ertan is located about $400 \mathrm{~km}$ northeast to Binchuan (Fig. 1). $\varepsilon_{\mathrm{Nd}}(t)$ values of the Ertan lavas show a stratigraphic variation roughly similar to that observed at Binchuan, other two parameters do not show coherent variations (Fig. 12b). The relatively high $\mathrm{Sm} / \mathrm{Yb}$ ratio is confined to the HT3 samples that may have a CLM origin. There is no overlap in composition in the Ertan and Binchuan sections. The Binchuan section contains HT1 and LT lavas, whereas the Ertan section contains HT2 and HT3 lavas (Fig. 2). This may reflect the spatial variation of the Emeishan flood basalts. To further east, the lavas in eastern Yunnan (EM-1, EM-3) and Guizhou province are all HT1 lavas and no LT type has been documented (Huang, 1986; Zhang et al., 1988; Xu et al., in preparation). The Emeishan LIP displays a spatial chemical variation, with the dominant LT lavas in the western province and the HT lavas in the eastern province. As shown previously, the least-contaminated HT and LT lavas have different REE composition and may reflect different melting depth. The spatial variation between them may reflect a variable lithospheric thickness beneath the Emeishan province and mantle potential temperature during the Permian-Triassic Period.

Given the presence of picritic lavas and thickest preserved lava succession $(>5000 \mathrm{~m})$ in the western province, the plume center was likely in the western province (Chung et al., 1998). In this axial area of the plume, the mantle temperature was high enough to initiate melting at relatively great depth (garnet stability) and continue to the shallow level (spinel stability). The melts derived from such a large degree of melting of mantle peridotites in the absence of garnet evolved to form the LT basalts (low REE abundance and low $\mathrm{Sm} / \mathrm{Yb}$ ratio). Due to upward heat transfer from the mantle, the overlying continental crust was incubated so that it became warmer and favorable for being assimilated into the magma 
chambers. This assimilation accounts for the lithospheric signature observed in most LT lavas. In contrast, in the periphery of the LIP (i.e., Guizhou Province), the lithospheric thickness was greater and the geotherm was lower than those underneath the axial area. This eventually led the melting column to have confined within the garnet stability field and a relatively low degree of melting. The low degree melts (with garnet residue in the source) evolved during ascent to form the HT basalts of high $\mathrm{Sm} / \mathrm{Yb}$ ratios. Due to the relatively cooler geothermal structure in the lithosphere, the magmas may have arisen more rapidly without pronounced assimilation by crustal materials.

\section{Conclusions}

(1) Based on geochemical variation, the Emeishan LIP lavas can be classified into two major magma types (i.e., LT and HT). The HT lavas can be further divided into three subtypes (HT1, HT2 and HT3). The LT lavas display relatively high $\mathrm{Mg \#} \mathrm{(0.51-}$ $0.63)$, low REE concentrations, depletions in $\mathrm{Nb}$ and Ta and low $\varepsilon_{\mathrm{Nd}}(t)$ values. In contrast, the HT magmas show a more evolved nature, with lower $\mathrm{Mg \#}$ (0.45-0.3) and higher incompatible element abundance. The variation in major element compositions of the LT and HT3 lavas is ascribed to ol + cpx fractionation in a deep level. In contrast, gabbroic fractionation in a shallow level accounts for the chemical variation of the HT1 and HT2 lavas. However, the chemical variation of HT and LT lavas cannot be described as simple crystal fractionation from a common parental magma. We propose that the parental magmas of the LT lavas were produced by a larger degree $(16 \%)$ of partial melting of mantle plume at shallower depth (depth to top of melting column $<60 \mathrm{~km})$ than those of the HT lavas $(1.5 \%$, $>75 \mathrm{~km})$.

(2) The correlation between $\mathrm{Sr}-\mathrm{Nd}$ isotopic and certain trace element ratios provide evidence for the involvement of various mantle and crustal components in the petrogenesis of the Emeishan flood basalts. Two distinct mantle components may have been involved in generation of the LT and HT1-HT2 lavas; the HT1 and HT2 basalts originated most likely from an OIB-like mantle source $\left({ }^{87} \mathrm{Sr} /{ }^{86} \mathrm{Sr}(t)\right.$ $\left.\approx 0.704, \varepsilon_{\mathrm{Nd}}(t) \approx+5\right)$, a slightly enriched mantle component $\left({ }^{87} \mathrm{Sr} /{ }^{86} \mathrm{Sr}(t) \approx 0.705, \varepsilon_{\mathrm{Nd}}(t) \approx+2\right)$ is required for the LT lavas. Different crustal plumbing systems may have operated in the compositional evolution of these magma types. The HT1 lavas have experienced an AFC style of contamination in the upper crust. The HT2 lavas may have been contaminated by melts derived from a gabbroic layer that was ponded near the crust-mantle boundary, resulting in the U-Th depletion in the basalts. In contrast, a temperature-controlled style of contamination was associated with the LT lavas. Both CLM and the upper crust may have participated in the contamination process. Origin of the HT3 lavas is less well constrained due to the limited number of samples. This magma type may have a petrogenesis completely different from those for the LT lavas and other HT magma types, and thus deserves further investigation.

(3) The available data provide some preliminary constraints on the temporal and spatial variation of the Emeishan flood basalts. The LT lavas are largely confined to the lower sequence of volcanic successions in the western part of the Emeishan LIP. This magma type represents the main phase of the volcanism, and is overlain by the HT lavas. To the east in the Guizhou Province of the LIP's margin, the lavas consist uniformly of the HT1 magma type. This temporal variation in the basalt chemistry (i.e., from LT to HT) indicates not only a deepening of the melting column, but also the transition from the peak to the waning stage of the mantle plume activity. This transition is apparently the reverse of that observed in other major CFBs but is similar to the chemostratigraphic variation observed in the Parana flood basalts (Peate et al., 1990) and in the Maymecha River basin in the Siberian flood volcanic province (Arndt et al., 1998). We suggest that the currently available samples were mainly from the middle to upper part of the entire lava succession of the Emeishan LIP. Systematic sampling of the early phases of volcanism is urgently needed. The spatial variation in rock type, on the other hand, is likely controlled by the difference of lithospheric thickness and mantle geothermal structure. Consequently, the LT lavas were generated probably in the plume axis region where the geotherm was higher and the lithosphere was thinner. In contrast, the HT lavas resulted from 
melting of the mantle at the plume periphery via lower degrees of melting due to lower temperature and thicker lithosphere.

\section{Acknowledgements}

We thank K.-L. Wang, M. LeCoz-Bouhnik, O. Henin, J. Macé and N. Morin for help with elemental and isotopic analyses. Prof. Dan McKenzie is thanked for the permission to use the INVMEL program and particularly for his patient guidance in employing the program. The constructive reviews of D. Peate and Z. Peng greatly improved the early version of this paper. The study benefited from financial supports by the National Science Council of Taiwan, CNRS of France, the Chinese Ministry of Science and Technology (G1999043205) and Chinese Academy of Sciences (KZCX2-101).

\section{References}

Arndt, N.T., Christensen, U., 1992. The role of lithospheric mantle in continental flood volcanism: thermal and geochemical constraints. J. Geophys. Res. 97, 10967-10981.

Arndt, N.T., Czamanske, G.K., Wooden, J.L., Fedorenko, V.A., 1993. Mantle and crustal contributions to continental flood volcanism. Tectonophysics 223, 39-52.

Arndt, N.T., Chauvel, C., Czamanske, G.K., Fedorenko, V.A., 1998. Two mantle sources, two plumbing systems: tholeiitic and alkaline magmatism of the Maymecha River basin, Siberian flood volcanic province. Contrib. Mineral. Petrol. 133, 297-313.

Campbell, I.H., Griffiths, R.W., 1990. Implications of mantle plume structure for the evolution of flood basalts. Earth Planet. Sci. Lett. 99, 79-93.

Chung, S.L., Jahn, B.M., 1995. Plume-lithosphere interaction in generation of the Emeishan flood basalts at the Permian-Triassic boundary. Geology 23, 889-892.

Chung, S.L., Jahn, B.M., Chen, S., Lee, C.Y., Chen, C.-H., 1995. Miocene basalts in NW Taiwan: evidence for EM-type mantle sources in the continental lithosphere. Geochim. Cosmochim. Acta 59, 549-555.

Chung, S.L., Lee, T.Y., Lo, C.H., Wang, P.L., Chen, C.Y., Nguyen, T.Y., Tran, T.H., Wu, G.Y., 1997. Intraplate extension prior to continental extrusion along the Ailao Shan-Red River shear zone. Geology 25, 311-314.

Chung, S.L., Jahn, B.M., Wu, G.Y., Lo, C.H., Cong, B.L., 1998. The Emeishan flood basalt in SW China: a mantle plume initiation model and its connection with continental break-up and mass extinction at the Permian-Triassic boundary. In:
Flower, M.F.J., Chung, S.L., Lo, C.H., Lee, T.Y. (Eds.), Mantle Dynamics and Plate Interaction in East Asia. AGU Geodyn. Ser., vol. 27, AGU, Washington, D.C., pp. 47-58.

Coffin, M.F., Eldholm, O., 1994. Large igneous provinces: crustal structure, dimension, and external consequences. Rev. Geophys. 32, 1-36.

Cox, K.G., 1980. A model for flood basalt volcanism. J. Petrol. 21, 629-650.

DePaolo, D.J., 1981. Trace element and isotopic effects of combined wallrock assimilation and fractional crystallization. Earth Planet. Sci. Lett. 53, 189-202.

Ellam, R.M., 1992. Lithospheric thickness as a control on basalt geochemistry. Geology 20, 153-156.

Ellam, R.M., Cox, K., 1991. An interpretation of Karoo picrite basalts in terms of interaction between asthenospheric magmas and the mantle lithosphere. Earth Planet. Sci. Lett. 105, 330342.

Fodor, R.V., 1987. Low- and high-TiO ${ }_{2}$ flood basalts of southern Brazil: origin from picritic parentage and a common mantle source. Earth Planet. Sci. Lett. 84, 423-430.

Frey, F.A., Garcia, M.O., Wise, W.S., Kennedy, A., Gurriet, P., Albarede, F., 1993. The evolution of Mauna Kea volcano, Hawaii: petrogenesis of tholeiitic and alkali basalts. J. Geophys. Res. 96, 14347-14375.

Gallagher, K., Hawkesworth, C.J., 1992. Dehydration melting and the generation of continental flood basalts. Nature 358, 57-59.

Garland, F.E., Turner, S.P., Hawkesworth, C.J., 1996. Shifts in the source of Parana basalts through time. Lithos 37, 223-243

Harland, W.B., Armstrong, R.L., Cox, A.V., Craig, L.E., Smith, A.G., Smith, D.G., 1989. A Geological Time Scale. Cambridge Univ. Press, New York, 263 pp.

Hergt, J.M., Peate, D.W., Hawkesworth, C.J., 1991. The petrogenesis of Mesozoic Gondwana low-Ti flood basalts. Earth Planet. Sci. Lett. 105, 134-148.

Hirose, K., Kushiro, I., 1993. Partial melting of dry peridotites at high pressure: determination of compositions of melts segregated from peridotite using aggregates of diamond. Earth Planet. Sci. Lett. 114, 477-489.

Hofmann, A.W., 1988. Chemical differentiation of the Earth: the relationship between mantle, continental crust, and oceanic crust. Earth Planet. Sci. Lett. 57, 421-436.

Hofmann, A.W., Jochum, K.P., 1996. Source characteristics derived from very incompatible trace elements in Mauna Loa and Mauna Kea basalts, Hawaii Scientific Drilling Project. J. Geophys. Res. 101, 1831-1839.

Huang, K.N., 1986. The petrological and geochemical characteristics of the Emeishan basalts from SW China and the tectonic setting of their formation ( $\mathrm{PhD}$ thesis). Institute of Geology, Academy Sinica (in Chinese).

Huang, K.N., Opdyke, N.D., 1998. Magnetostratigraphic investigations on an Emeishan basalt section in western Guizhou province, China. Earth Planet. Sci. Lett. 163, 1-14.

Huang, K.N., Opdyke, N.D., Peng, X.J., Li, J.G., 1992. Paleomagnetic results from the Upper Permian of the eastern Qiangtang Terrane of Tibet and tectonic implications. Earth Planet. Sci. Lett. 111, 1-10.

Huppert, H.E., Sparks, R.S.J., 1985. Cooling and contamination of 
mafic and ultramafic magmas during ascent through continental crust. Earth Planet. Sci. Lett. 74, 371-386.

Kerr, A., 1994. Lithospheric thinning during the evolution of continental large igneous provinces: a case study from North Atlantic Tertiary province. Geology 22, 1027-1039.

Klein, E.M., Langmuir, C.H., 1987. Global correlation of ocean ridge basalt chemistry with axial depth and crustal thickness. J. Geophys. Res. 92, 8089-8115.

Lassiter, J., Depaolo, D., 1997. Plume/lithosphere interaction in the generation of continental and oceanic flood basalts: chemical and isotopic constraints. In: Mahoney, J., Coffin, B. (Eds.), Large Igneous Provinces: Continental, Oceanic and Planetary Flood Volcanism. AGU Geophys. Monogr., vol. 100, AGU, Washington, D.C., pp. 335-356.

Lin, J.Y., 1985. Spatial and temporal distribution of Emeishan basaltic rocks in three southwestern province (Sichuan, Yunnan and Guizhou) of China. Chin. Sci. Bull. 12, 929-932 (in Chinese).

Mahoney, J.J., Coffin, M.F. (Eds.), Large Igneous Provinces: Continental, Oceanic and Planetary Flood Volcanism. AGU Geophys. Monogr., vol. 100, AGU, Washington, D.C., 438 pp.

McKenzie, D.P., Bickle, M.J., 1988. The volume and composition of melt generated by extension of the lithosphere. J. Petrol. 29, 625-679.

McKenzie, D.P., O’Nions, R.K., 1991. Partial melt distributions from inversion of rare earth element concentrations. J. Petrol. 32, 1021-1091.

Peate, D.W., 1997. The Parana-Etendeka Province. In: Mahoney, J., Coffin, B. (Eds.), Large Igneous Provinces: Continental, Oceanic and Planetary Flood Volcanism. AGU Geophys. Monogr., vol. 100, pp. 217-246.

Peate, D.W., Hawkesworth, C.J., Mantovani, M.S.M., Shukovsky, W., 1990. Mantle plumes and flood basalt stratigraphy in the Parana, South America. Geology 18, 1223-1226.

Peate, D.W., Hawkesworth, C.J., Mantovani, M.S.M., 1992. Chemical stratigraphy of the Parana lavas (south America): classification of magma-types and their spatial distribution. Bull. Volcanol. 55, 119-139.

Peng, Z.X., Mahoney, J., Hooper, P., Harris, C., Beane, J., 1994. A role for lower continental crust in flood basalt genesis? Isotopic and incompatible element study of the lower six formations of the Western Deccan Traps. Geochim. Cosmochim. Acta 58, 267-288.

Renne, P.R., Zhang, Z.C., Richards, M.A., Black, M.T., Basu, A.R., 1995. Synchrony and causal relations between Permian-Triassic boundary crises and Siberian flood volcanism. Science 269, 1413-1416.
Sichuan (Anonymous), 1991. Regional geology of Sichuan province. Geol. Mem. Series, vol. 23. Geologic Press, Beijing, 730 pp. (in Chinese).

Stolper, E., 1980. A phase diagram for mid-ocean ridge basalts: preliminary results and implications for petrogenesis. Contrib. Mineral. Petrol. 74, 13-27.

Sun, S.-S., McDonough, W.F., 1989. Chemical and isotopic systematics of oceanic basalts: implications for mantle composition and processes. In: Saunders, A.D., Norry, M.J. (Eds.), Magmatism in the Ocean Basins. Spec. Publ., vol. 42, Geol. Soc., London, pp. 313-345.

Tapponnier, P., Lacassin, R., Leloup, P.H., Scharer, U., Zhong, D.L., Wu, H.W., Liu, X.H., Ji, S.C., Zhang, L.S., Zhong, J.Y., 1990. The Ailao Shan-Red River metamorphic belt: tertiary left-lateral shear between Indochina and South China. Nature 343, 431-437.

Turner, S., Hawkesworth, C., 1995. The nature of subcontinental mantle: constraints from the major-element composition of continental flood basalts. Chem. Geol. 120, 295-314.

Weaver, B.L., 1991. The origin of ocean island basalts end-member composition: trace element and isotopic constraints. Earth Planet. Sci. Lett. 104, 381-397.

White, R.S., McKenzie, D.P., 1995. Mantle plume and continental flood basalts. J. Geophys. Res. 100, 17543-17585.

White, R.S., McKenzie, D., O’Nions, K., 1992. Oceanic crustal thickness from seismic measurement and rare earth element inversion. J. Geophys. Res. 97, 19683-19715.

Wooden, J.L., Czamanske, G.K., Pedorenko, V.A., Arndt, N.T., Chauvel, C., Bouse, R.M., King, B.-S., Knight, R.J., Siems, D., 1993. Isotopic and trace element constraints on mantle and crustal contribution to Siberian continental flood basalts, Noril'sk area, Siberia. Geochim. Cosmochim. Acta 57, 36773704.

Xu, Y.G., Chung, S.L., 2001. The Emeishan Large Igneous Province: evidence for mantle plume activity and melting conditions. Geochimica 30, 1-9 (in Chinese with English abstract).

Yuan, X.C., 1989. On the deep structure of the Kang-dian rift. Acta Geol. Sin. 63, 1-13 (in Chinese).

Yunnan (Anonymous), 1990. Regional geology of Yunnan province. Geol. Mem. Series, vol. 21. Geologic Press, Beijing, 728 pp. (in Chinese).

Zhai, M.G., Yang, R.Y., 1986. Early precambrian gneiss basement in the Panxi area, southwest China. Acta Pet. Sin. 2, 22-37 (in Chinese).

Zhang, Y.X., Luo, Y., Yang, X., 1988. The Panxi Rift. Geological Press, Beijing (in Chinese). 